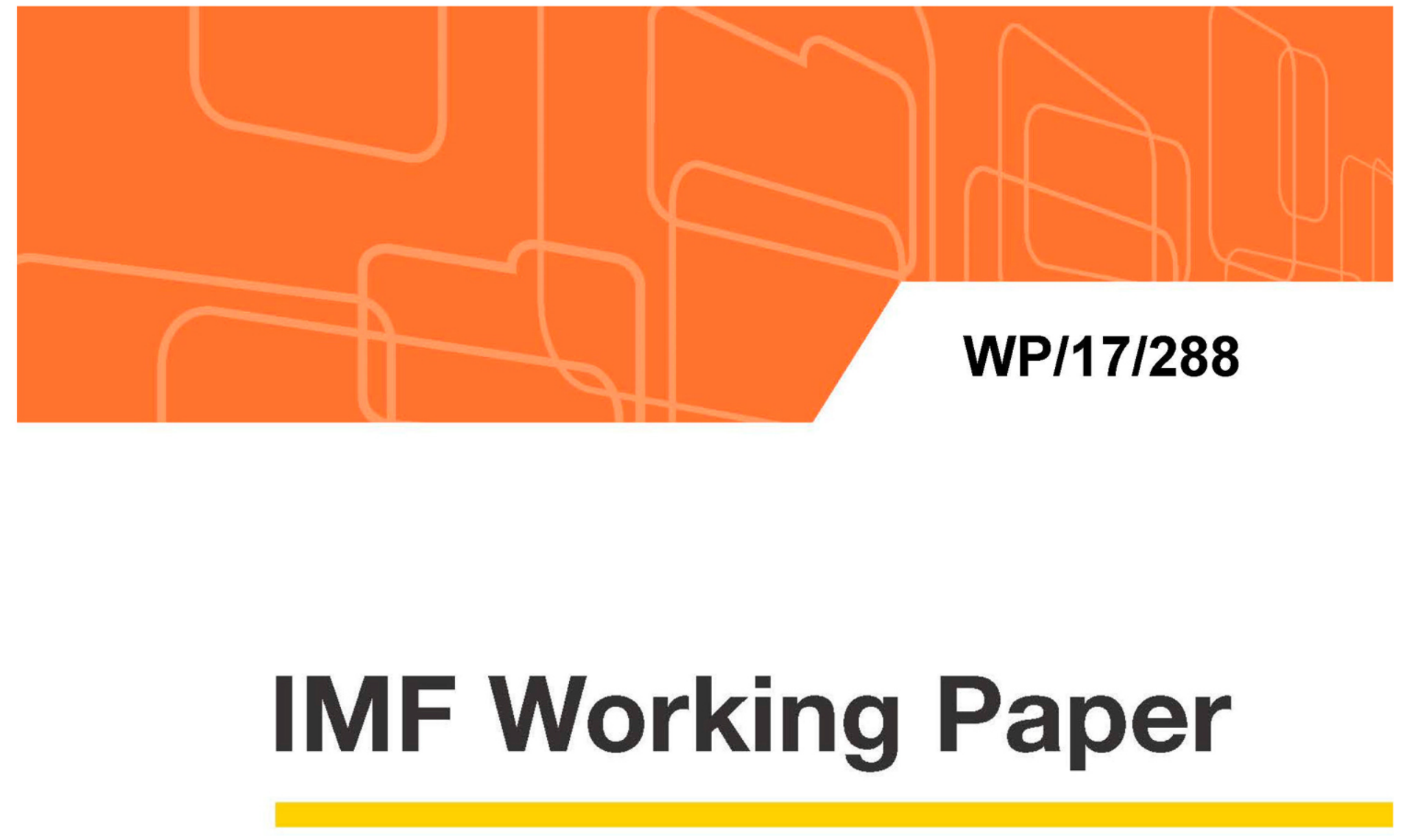

\title{
China's Impacts on SSA through the Lens of Growth and Exports
}

by Yibin Mu, Chu Wang, Dong Frank Wu

IMF Working Papers describe research in progress by the author(s) and are published to elicit comments and to encourage debate. The views expressed in IMF Working Papers are those of the author(s) and do not necessarily represent the views of the IMF, its Executive Board, or IMF management.

$$
\text { I N T E R N A T I O N A L M O N E T A R Y F U N D }
$$




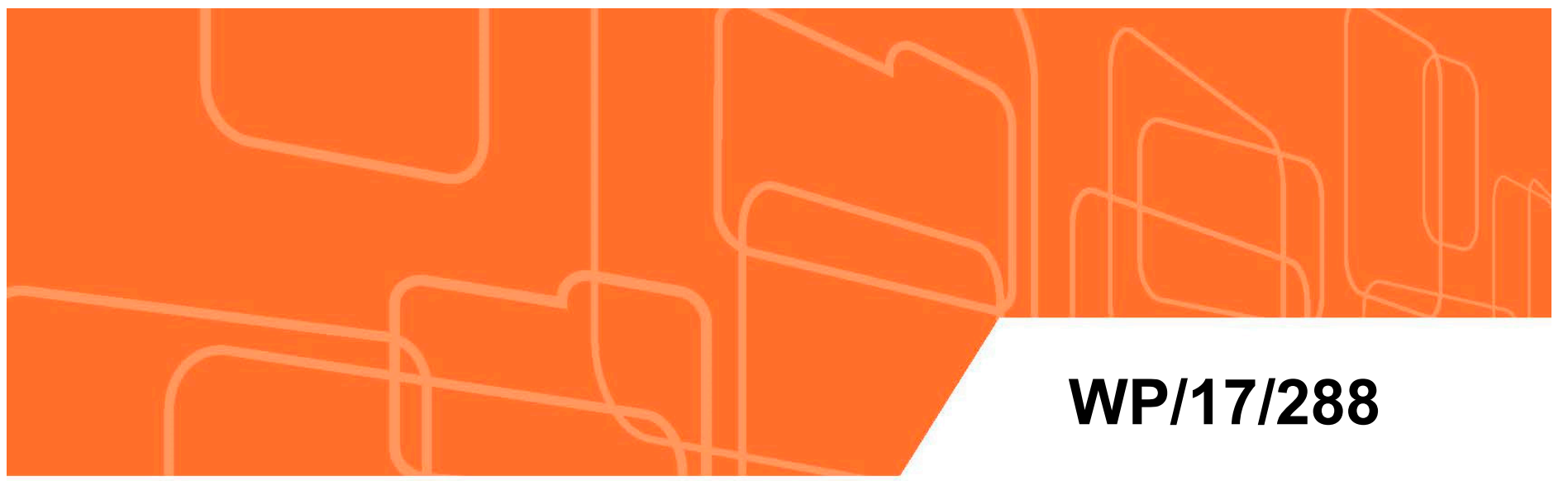

\section{China's Impacts on SSA through the Lens of Growth and Exports}

by Yibin Mu, Chu Wang, Dong Frank Wu

IMF Working Papers describe research in progress by the author(s) and are published to elicit comments and to encourage debate. The views expressed in IMF Working Papers are those of the author(s) and do not necessarily represent the views of the IMF, its Executive Board, or IMF management. 
IMF Working Paper

African Department

\title{
China's Impacts on SSA through the Lens of Growth and Exports* \\ Prepared by Yibin Mu, Chu Wang, Dong Frank Wu
}

Authorized for distribution by Ali Mansoor

December 2017

\section{IMF Working Papers describe research in progress by the author(s) and are} published to elicit comments and to encourage debate. The views expressed in IMF Working Papers are those of the author(s) and do not necessarily represent the views of the IMF, its Executive Board, or IMF management.

\begin{abstract}
The analysis of China's impacts on the 44 SSA countries reveals that: (i) after joining the WTO in 2001, China has started to impact significantly on SSA growth: one-percent increase in China's GDP per capita leads to 0.02 percent increase on the SSA's GDP per capita; (ii) oil and investment-goods exporters benefit more from China's growth; (iii) compared to China's consumption, its investment growth acts as a more important channel in influencing SSA; (iv) exports to China, highly linked to China's growth, is an important indicator for SSA's exports. Our results call for SSA countries to be well prepared for China's rebalancing given its growing economic influence and to proactively search a sustainable way to continuously enhance productivity.
\end{abstract}

JEL Classification Numbers: F40, O11, O47

Keywords: Exports, Growth, Development, China Economy, SSA

Author's E-Mail Address: YMu@imf.org, CWang@imf.org, DWu@imf.org

\footnotetext{
* The authors are grateful for the support of Roger Nord, Ali Mansoor, and Lisandro Abrego. We thank all the helpful comments received at the departmental presentations and during the circulation process. All errors are ours.
} 


\section{CONTENTS}

ABSTRACT

I. INTRODUCTION $\underline{4}$

II. LITERATURE REVIEW $\underline{6}$

III. DATA AND METHODS

Data

Methods

IV. EMPIRICAL RESULTS

SSA' Growth

SSA' Goods Exports to the World

SSA' Goods Exports to China

V. CONCLUSION $\underline{21}$

REFERENCES $\underline{23}$

APPENDIX $\underline{25}$

\section{FIGURES}

Figure 1. Growth of GDP per capita: China vs the World

Figure 2. SSA's Exports and China's Growth

TABLES

Table 1 Simple correlations of Growth of GDP per capita with SSA

Table 2.1 Growth per capita of SSA countries and China's Growth (1994-2015 vs 2003-15)___

Table 2.2 Growth per capita of SSA Sub-groups and China's Growth (2003-15) ___

Table 2.3 Growth per capita of SSA Sub-groups and China's Growth (2003-15)

Table 2.4 Growth per capita of SSA Sub-groups and China's Consumption and Investment (2003-15) _

Table 3.1 Total Exports of SSA, Growth (2003-15)

Table 3.2 Total Exports of SSA Sub-groups, Growth (2003-15)

Table 3.3 Total Exports of SSA Sub-groups, Growth (2003-15)

Table 3.4 Total Exports of SSA Sub-groups, Growth (2003-15)

Table 4.1 Exports to China of SSA, Growth (2003-15)

Table 4.2 Exports to China of SSA Sub-groups, Growth (2003-15)

Table 4.3 Exports to China of SSA Sub-groups, Growth (2003-15)

\section{APPENDIX TABLES}

Table A1. Analytical Categorization of the Global Economy $\underline{25}$

Table A2. Analytical Categorization of SSA countries by Trade Ties with China___ 26

Table A3. Analytical Categorization of SSA Countries by AFR REO

Table A4. Analytical Categorization of SSA Countries by Papageorgiou and Xie (2016)___ 27

Table A5. Descriptive Statistics of Growth Regression (1994-2015)

Table A6. Descriptive Statistics of Growth Regression (2003-15)

Table A7. Descriptive Statistics of Exports Regression (2003-15) 


\section{INTRODUCTION}

China's economic performance, since early 1980s, is phenomenal by various criteria, characterized by long-duration, high growth rate and world-wide spillover effects. The 36-year average growth rate of China's GDP per capita is as high as 8.8 percent while the global economy experienced an average growth rate of 2.4 percent (Figure 1). The rapid economic expansion has made China's economy more influential in the global economy and thus attracted more researchers' attention.

Numerous papers have studied the growing economic power China has exerted at different economic aspects, on various regions or countries, and via various channels. Most of them assume that China's spillover has increased proportionately with its economic output (or trade) without experiencing any structural break, but this may not be underpinned by observations especially when we consider a series of economic reforms and initiatives accompanying China's growth which have amplified the magnitude of China's global influence in an exponential way.

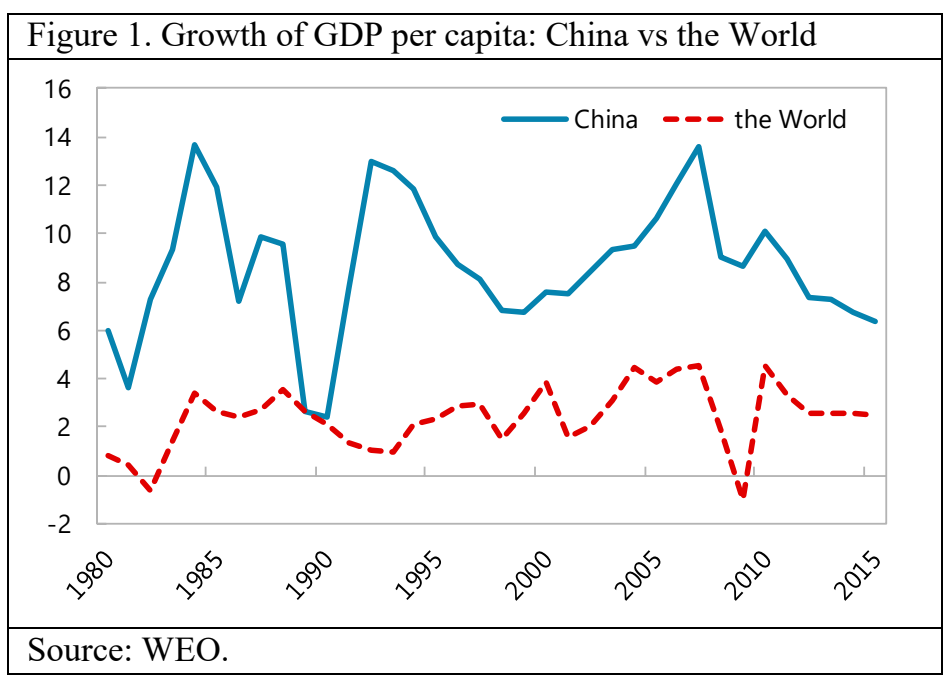

As Figure 2 shows, exports from Sub-Sahara Africa (SSA) to China has increased dramatically in the past two decades, particularly after 2001 when China joined the WTO. Surpassing the US in 2012, China has become the second largest exporting partner of SSA only after EU. Table $1^{1}$ conveys a similar message by raising an interesting question: is it possible that the magnitude of China's impacts on SSA is significantly different before and after a certain time point around the year of 2002? Please be advised that the paper does not infer any conclusion from the simple correlations of growth of GDP per capita. Actually, Table 1 shows all other three country groups

\footnotetext{
${ }^{1}$ To give readers a general sense about the growing economic synchronization between China and SSA, the simple correlation is computed while more rigorous empirical analysis will be presented in the following sections.
} 
also experience jumps in correlations with SSA. More quantitative analysis will be provided in the following sections, which forms the basis for our conclusion.

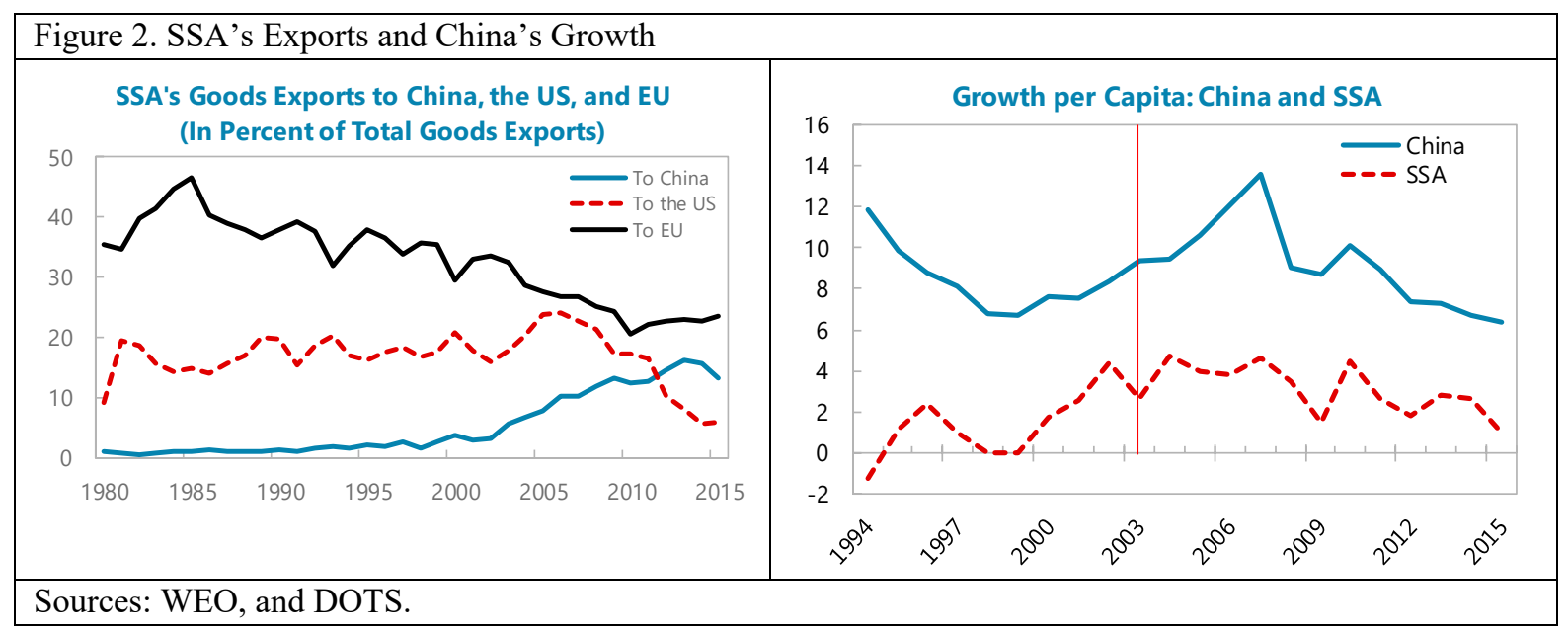

\begin{tabular}{|lrr|}
\hline Table 1. Simple correlations of Growth of GDP per capita with SSA \\
\hline
\end{tabular}

Guided by these observations, the paper does not take for granted that China's impacts on SSA remain structurally stable since 1980 . Instead, we run regressions with different sample periods to check the existence of a structural break in China's impacts. The regression results and economic intuition jointly direct the study to focus on the period of 2003 to 2015 due to the implied structural break stemming from China joining the WTO.

Given vast variation in economic characteristics among 44 SSA countries, it is meaningful to explore the implications of country heterogeneity on the degree of economic dependence on China. For example, iron-ore-exporting countries may heavily rely on China's construction industry while SSA countries exporting cotton are likely to be sensitive to China's domestic consumption. Accordingly, this paper divides SSA countries into groups following wellaccepted criteria and investigates common features for each group.

Another interesting angle to gauge China's impacts is to disaggregate China's growth into consumption and investment to quantify the exact effects of China's GDP components. This growth disaggregation also contributes to the study of what role SSA country heterogeneity play for China's impacts just as mentioned in the paragraph above. 
If China's impacts on SSA are well quantified, a following question would be what the potential transmission channels are? how China influences SSA? In this context, the paper seeks to assess the traditional channels of trade and FDI by examining whether China-related variables are among the determinates of SSA's total exports and exports to China.

In summary, the paper seeks to answer the following questions:

1. Is China's economic growth significant for SSA growth? Does it evolve over time?

2. Does country heterogeneity play a role?

3. Which component of China's GDP is more important: consumption or investment?

4. What role does Chinese economy play in SSA's exports?

For China's impacts on SSA's GDP growth, the paper follows the setup of classic growth literature and adopt the difference GMM approach to address regressor endogeneity. This method can provide more reliable empirical results on China's spillover to SSA, which is instrumental in policymakers' understanding the potential economic implications of China's rebalancing, namely lower growth rates accompanied by a shift from investment-driven to consumption-driven economic model.

The paper is organized as follows: section II reviews relevant literature on growth and economic ties between China and SSA and highlights our contributions; section III presents data and empirical methods; section IV provides regression results; and section V concludes the paper with policy implications.

\section{LITERATURE REVIEW}

IMF (2016) points out three identified spillover channels through which China may influence the world economy: trade, external financing and commodity prices. Research by Hong et al (2016) investigates the reason of China's imports slowing down and estimates its impacts on Asia countries. Blagrave and Vesperoni (2016) sets up a panel VAR and quantifies the spillover effects of China's economic transition on exports of advanced economies and emerging markets. Dizioli et al (2016) focuses their analysis on China's spillovers on ASEAN-5 economies via trade, commodity prices and financial markets. Empirical work focusing on China's influence on financial markets includes Cashin et al (2016), Arslanalp et al (2016) and Mwase et al (2016). Kolerus et al (2016) assesses empirically Chinese impacts on global commodities markets. This paper complements the existing research by specifically quantifying China's impacts on SSA.

This paper builds on existing literature and contributes to the literature examining China's presence in SSA and the potential linkages between them. The recent paper by Chen and Nord (2017) has examined the possible impacts of China's new growth model on SSAs. Their results confirm the significance of trade ties between China and SSA, especially between China and 
investment-driven commodity exporters, consistent with findings from Kireyev and Leonidov (2016), and Blagrave and Vesperoni (2016). Drummond and Liu (2013) estimates the impact of China's fixed assets investment (FAI) on SSA countries' exports to China with data of 19952012. Their findings include that a one-percent increase (or decline) in China's domestic investment growth is associated with an average 0.6 percent increase (or decline) in SSA countries' export growth, which will be re-assessed in our paper. Instead, our analysis centers on China's impacts on SSA countries with an effort to identify the potential transmission channels while factoring in the structural break.

Our work is also related to literature studying the relationship on growth and openness. Many papers have documented a positive spillover from trading partners. For instance, Arora and Vamvakidis (2004) shows generally trading partners' growth and relative income levels have strong effects on domestic growth based on data of more than 100 countries. Recent paper by Papageorgiou and Xie (2016) focus on low income countries (LICs) and find advanced economies and emerging markets, especially China, contributing significantly to the economic growth of LICs.

Papers drawing on firm-level data paint a quite different picture on the economic relations between China and SSA. Ceglowski et al (2015) finds that China overwhelmingly exports manufactured products to SSA and most SSA countries are unlikely to be competitive in laborintensive manufacturing. Jenkins and Edwards (2015) analyzes the impact of Chinese competition on South African manufacturing exports to its major markets in Europe, the U.S. and SSA. These studies necessitate a comprehensive assessment of China's spillover while taking into account all relevant forces at the aggregated level, which would be much helpful for SSA's policy-making and is what this paper aims to achieve.

\section{DATA AND MeTHODS}

\section{Data}

The data sources for this study include the World Economic Outlook (WEO), Direction of Trade Statistics (DOTS), International Finance Statistics (IFS), the World Development Indicators (WDI) of the World Bank, and the China Africa Research Initiative (CARI) dataset of Johns Hopkins University.

Our dependent variable, GDP per capita for each SSA country, comes from WDI, which contains numbers in constant USD.

Our main independent variables, growth rates of GDP and GDP per capita for each country in the world, are both retrieved from WEO, which are then used to calculate the exports-weight 
growth rate for each SSA country. Details on computation are explained in the following part of the paper.

Ratios of investment to GDP, government consumption to GDP, broad money to GDP, and headline inflation for each SSA country also come from WEO. Data on NEER and TOT come from IFS and WEO respectively. Population data are retrieved from WDI. Exports data come from DOTS and WDI, and data of China's FDI to SSA come from CARI.

\section{Methods}

To tackle the four questions listed in the introduction, the paper includes the three major regressions: (i) Regress SSA GDP-per-capita growth on trading partners' growth; (ii) regress SSA total exports growth on trading partners' growth with a special focus on China's influence; and (iii) investigate the determinants of SSA's exports to China.

For the regression on growth, the paper draws on the standard cross-country empirical work of economic growth which normally has the following equation specification:

$\ln \left(y_{i, t}\right)-\ln \left(y_{i, t-\tau}\right)=\alpha_{1} * \ln \left(y_{i, t-\tau}\right)+G_{i, t} \varphi+X_{i, t} \beta+\mu_{i}+\eta_{t}+\varepsilon_{i, t}$

$\ln \left(y_{i, t}\right)$ is the logged value of GDP per capita in constant USD for country $i$ at period $t$ while $\ln \left(y_{i, t}\right)-\ln \left(y_{i, t-\tau}\right)$ is an approximation of GDP per capita growth. As classic growth literature proposes, the growth rate of GDP per capita is a function of GDP per capita of last period and other control and relevant variables represented by $G_{i, t}, X_{i, t}$. The neoclassical growth model predicts a negative coefficient for the initial per capita GDP level, $\alpha_{1}$. This is consistent with the hypothesis that the closer the country is to the equilibrium per capita income level, the slower the convergence rate the country experiences.

Equation (1) can be re-written, for regression purposes:

$\ln \left(y_{i, t}\right)=\left(1+\alpha_{1}\right) * \ln \left(y_{i, t-\tau}\right)+G_{i, t} \varphi+X_{i, t} \beta+\mu_{i}+\eta_{t}+\varepsilon_{i, t}$

$G_{i, t}$ is the row vector of trading partners' growth. Given that this paper aims to analyze China's impacts, this paper singles out China as one separate force and then divides the rest of the world economy into four groups: advanced economies (AE), emerging markets (EM), peer SSA countries (SSA) and the rest of the world (ROW). ${ }^{2}$ As proposed by Arora and Vamvakidis (2004), the paper calculates the growth rate of GDP per capita for each group using exports as weights following the formula below:

$$
\left\{\sum_{j}\left[\left(\frac{G D P_{j, s}}{G D P_{j, s-1}}-1\right) * \frac{\operatorname{exports}_{i j, s}}{\sum_{j} \operatorname{exports}_{i j, s}}\right]\right\}
$$

\footnotetext{
${ }^{2}$ A list of country names for each category is appended at the end of the paper.
} 
This is the trade partner's growth for county $i$ at period $s$, which sums up all the exportsweighted growth rates of each country in these country group. For the denominator of the weight, there are two options: one is to use total exports to all the countries in the group, and the other is to use total exports to the world. Either method has its own pros and cons. The supporters of using total exports to the world as the weight's denominator hold the view that this type of weight computation accurately captures the dynamics of the relative importance of each trade partner. Thought, this type of data compilation certainly amplifies the correlation between the growth between trade partners and SSA exporting countries. To keep regression results reliable, the paper decides to use total exports to the countries within the same group, which implies that SSA countries have different growth rates for trade partners group ${ }^{3}$, but faces the same China's growth in the regression.

$X_{i, t}$ are other control variables, including: investment-to-GDP, government-consumption-toGDP, M2-to-GDP, headline inflation, openness and terms of trade. Following the basic regression set up of Caselli et al (1996), ratios of investment to GDP and government consumption to GDP are added to control for domestic expenditure environment. The ratio of broad money to GDP represents the monetary policy stance, which may influence the economic activities by impacting the liquidity condition and aggregate demand. Headline inflation is included as an important parameter for domestic economic environment. High and volatile inflation discourages private investment and undermines long-term growth potential. Country's openness helps capture the country exposure to the world economy and the vulnerability of country economy to external shocks. Terms of trade is included to measure the cross-border transaction conditions. One possible candidate variable to be added into this vector is capital inflow, but it is dropped from the regression because investment and physical capital level have been covered in variables of the investment to GDP ratio and per capita GDP. ${ }^{4}$

$\mu_{i}$ is the unobservable country-specific effect and $\eta_{t}$ represents time-variant global shocks.

$\Delta \ln \left(y_{i, t}\right)=\left(1+\alpha_{1}\right) * \Delta \ln \left(y_{i, t-\tau}\right)+\Delta G_{i, t} \varphi+\Delta X_{i, t} \beta+\Delta \eta_{t}+\Delta \varepsilon_{i, t}$

The strategy for growth regression is borrowed from Caselli et al (1996) and Levine et al (2000), both of which applies the GMM method. The appearance of lagged dependent variable, $\ln \left(y_{i, t-\tau}\right)$, on the right side of the regression equation makes endogeneity issue worse such that the regular panel data "within estimator" or "GLS estimator" become asymptotically inconsistent, which is also labelled as Nickel (1981) bias. The difference GMM method (developed by Holtz-Eakin, Newey and Rosen (1988), Arellano and Bond (1991),) is used in this paper to tackle this issue by utilizing lagged value of weakly endogenous regressors. ${ }^{5}$

\footnotetext{
${ }^{3}$ Please note that the exports-weight is a function of each SSA country's exports to every trade partner.

${ }^{4}$ Some may hold the view that capital inflows also facilitate skill and technology transfer, helping increase workers' productivity in host country.

${ }^{5}$ A good guidance note is written by David Roodman (2006).
} 
For the second regression on SSA exports to the world, the regression equation is:

$e x_{i, t}=\operatorname{ex} 2 C H N_{i, t} * \theta+\tilde{G}_{i, t} \tilde{\varphi}+\tilde{X}_{i, t} \tilde{\beta}+\mu_{i}+\eta_{t}+\varepsilon_{i, t}$

where $e x_{i, t}$ is the growth rate of total goods exports to the world in real term for each SSA country while $\operatorname{ex2CHN}$ i,t is the real growth rate of goods exports to China for each SSA country. Data of total goods exports is from WDI while Data of goods exports to China is calculated by dividing nominal exports to China in US dollars from DOTS with the derived US dollar deflator from WDI. Exports to China is added into the equation to test the idea that for most SSA countries, exports to China is an important indicator for their total exports. This is based on the following thoughts: most SSA countries are specialized in primary products' export, encompassing energy, base metal, and agricultural products. In the meantime, China has become the biggest marginal buyer on the global commodity markets, which means a demand spike from China could generate disproportional price fluctuations in the global markets. Furthermore, for some SSA countries, goods shipped to China take up a large share of their total exports. Angola, for example, has sold more than 30 percent of its total exports to China for the years of 2003 to 2015 .

$\tilde{G}_{i, t}$ is the vector of exports-weighted GDP growth rates for each trade partner group. Similar to the growth regression in the section above, China is singled out and the world economy is then divided into four groups: AE, EM, SSA and ROW. Here, the trade partner growth is proxied by GDP growth instead of GDP per capita growth because export numbers are aggregate statistics at national level and exporting firms in SSA normally account for only a limited portion of the whole working population. Also, population growth in each SSA country is added as a control on demographic factors.

$\tilde{X}_{i, t}$ includes headline inflation, nominal effective exchange rate (NEER) ${ }^{6}$, terms of trade $(\mathrm{TOT})^{7}$, population growth, and GDP per capita. Headline inflation is used to control for relevant domestic conditions. NEER and TOT are thought directly linked to export performance. Population growth is also added for reasons explained in the previous paragraph. GDP per capita is used to proxy the development stage and to control for initial conditions.

As usual, $\mu_{i}$ is inserted to control for the unobservable country-specific effect and $\eta_{t}$ for timevariant global shocks.

Fixed effect panel data approach is applied with cluster option to control for heteroscedasticity across SSA countries.

\section{The third regression explores the determinants of SSA exports to China:}

\footnotetext{
${ }^{6}$ Change rate of NEER, in percent.

${ }^{7}$ Change rate of TOT, in percent.
} 
$\operatorname{ex} C H N_{i, t}=g_{C H N, t} * \varphi+\overline{\bar{X}}_{i, t} \overline{\bar{\beta}}+\mu_{i}+\eta_{t}+\varepsilon_{i, t}$

$g_{C H N, t}$ is China's real growth.

$\overline{\bar{X}}_{i, t}$ includes headline inflation, NEER, TOT, population growth, GDP per capita, and China's FDI. Borenszteina et al (1998) reveal that FDI contributes to economic growth when the host economy has the capacity to absorb the advanced technologies available. Thus, this paper adds China's FDI into the regression. GDP per capita is kept in the regression to control for technological absorption and productivity.

Like the regressions above, country-specific and time-specific dummies are kept.

Similarly, the within estimator approach is applied with control for heteroscedasticity across SSA countries.

\section{EMPIRICAL RESULTS}

This section details regression procedures and explains the empirical results. As explained above, the quantitative analysis seeks to tackle three important topics: growth, exports to the world, and exports to China. In this section, panel data methods are applied. SSA sub-group regressions are conducted to reflect country heterogeneity and China's GDP components are utilized to identify deeper driving forces.

To investigate how country heterogeneity (or country type) contributes to the economic dependency on China's growth, the paper uses three criteria to divide the 44 SSA countries:

First, the paper divides SSA countries into two sub-groups based on their trade ties with China. We compute the 13-year-average ratio of exports to China relative to total exports for all SSA countries and label the top 22 as countries with strong trade ties with China while grouping the rest 22 as countries with weak trade ties with China (Table A2). This classification helps check whether close economic connection with China brings more spillovers to SSA countries' growth.

The second criterion is borrowed from IMF (2017), which divides SSA countries into three groups: oil exporters if net oil exports make up 30 percent or more of total exports, other resource-intensive countries if non-renewable exports is 25 percent or more, and non-resourceintensive countries if not falling into the previous two groups. This classification is adopted with the perception that energy and metal are two major resources that China seeks from its trading partners in SSA. Curiosity arises to see if China's impacts are linked to these types of cross-border transactions. 
Inspired by Papageorgiou and Xie (2016), the paper also lumps SSA countries into a third set of groups: net-commodity exporters if the share of commodity exports relative to total exports is at least 50 percent, or non-commodity exporters if not. Net-commodity exporters are used as a basis to generate two more sub-groups: net investment-driven exporters if net exports of investment-related goods exceed zero, and net consumption-driven exporters if net consumption-related exports exceed zero. It is worth noting that the two subgroups have overlaps: some countries belong to both (Table A4). This classification is helpful in examining whether China's rebalancing from investment to consumption has noticeable impacts on SSA economies.

\section{SSA' Growth}

Caselli et al (1996) take every five years as one observation to reduce serial correlation of error terms. Following their practice and factoring in the short period of our data (from 1994 to 2015), this paper takes three years as one period. For control variables and other relevant variables, we take three-year average starting from 1995. For state variable, such as GDP per capita, we take the natural log on a 3-period lag for each corresponding period. This means we use year 2012's per capita GDP as a state variable of year 2015 observation. To ensure the regression results have direct implications on annual growth rate, the logged GDP per capita is divided by the number of years in each observation. When the difference GMM method applies, postregression tests are necessary to check regression efficiency. Sargent $\mathbf{J}$ test and Hansen test are adopted for over-identifying restrictions ${ }^{8}$. In addition, autoregressive tests help decide the starting lag for weakly exogenous variables, and the requirement of the number of instruments less than the number of groups helps determine the maximum number of lags. All test results are recorded in the bottom panel of Table 2.1 .

When the whole sample period $(1994-2015)$ is used, all coefficients are insignificant except for lagged GDP per capita. Then, the sample period is shortened to the years of 2003 to 2015, which correspond to the period witnessing substantial increase in bilateral trade because of China joining the WTO in 2001 (Figure 2). The results become encouraging: China is the only one of the five economic groups, which has significant impacts on SSA's growth. As Table 2.1 ${ }^{9}$ shows, the regression with data from 1994 to 2015 neither has significant coefficients for trade partners, nor gets positive signs for China and AE. These counterintuitive results are likely due to structural breaks ${ }^{10}$. In this context, this paper chooses to start the sample period from 2003. As expected, the regression with the short period shows positive impacts of China's growth and insignificant-but-positive signs for AE, EM and peer SSA.

\footnotetext{
${ }^{8}$ The Sargent statistic of regression for the period of 2003-2015 implies a very low P-value, suggesting that the instruments may be weak. Given Hansen test is robust and does not reject the null hypothesis, the paper keeps the set-up.

${ }^{9}$ The implied convergence coefficient is equal to one minus the coefficient of state variable. For example, for the period of 2003-2015, the convergence coefficient is $-0.426(=0.574-1)$

${ }^{10}$ This is also mentioned in the spillover note by Blagrave and Vesperoni (2016).
} 


\begin{tabular}{|c|c|c|c|c|c|c|}
\hline \multirow{3}{*}{ State Variable } & \multicolumn{3}{|c|}{$1994-2015$} & \multicolumn{3}{|c|}{$2003-2015$} \\
\hline & Coef. & P-value & & Coef. & -value & \\
\hline & & & & & & \\
\hline $1 / 3 * \operatorname{Ln}($ GDP per capita of each SSA country) $(-3)$ & $0.560 * * *$ & 0.000 & $(5.53)$ & $0.574 * * *$ & 0.000 & $(5.00)$ \\
\hline \multicolumn{7}{|l|}{ Trade Parters' Growth } \\
\hline China's GDP per capita, Growth & -0.00333 & 0.451 & $(-0.75)$ & $0.0152^{* * *}$ & 0.010 & (2.58) \\
\hline AE's GDP per capita, Growth & -0.000866 & 0.917 & $(-0.10)$ & 0.00370 & 0.274 & (1.09) \\
\hline EM's GDP per capita, Growth & 0.00300 & 0.223 & $(1.22)$ & 0.0000845 & 0.953 & $(0.06)$ \\
\hline Peer SSA's GDP per capita, Growth & -0.00141 & 0.697 & $(-0.39)$ & 0.00108 & 0.335 & (0.96) \\
\hline ROW's GDP per capita, Growth & -0.00438 & 0.160 & $(-1.40)$ & -0.00156 & 0.388 & $(-0.86)$ \\
\hline \multicolumn{7}{|l|}{ Other Variables } \\
\hline Investment-to-GDP ratio & -0.000594 & 0.606 & $(-0.52)$ & -0.000351 & 0.745 & $(-0.32)$ \\
\hline Government-Consumption-to-GDP ratio & -0.000868 & 0.621 & $(-0.49)$ & -0.000399 & 0.798 & $(-0.26)$ \\
\hline M2-to-GDP ratio & -0.000534 & 0.423 & $(-0.80)$ & -0.000526 & 0.588 & $(-0.54)$ \\
\hline Headline Inflation & -0.000263 & 0.127 & $(-1.53)$ & $-0.000234^{*}$ & 0.100 & $(-1.65)$ \\
\hline Openness & -0.0000387 & 0.919 & $(-0.10)$ & -0.000121 & 0.748 & $(-0.32)$ \\
\hline TOT, change rate & 0.000423 & 0.347 & $(0.94)$ & 0.000171 & 0.425 & $(0.80)$ \\
\hline N. of Observations & 234 & & & 206 & & \\
\hline N. of Groups & 42 & & & 42 & & \\
\hline Observations per group: min & 3 & & & 3 & & \\
\hline Observations per group: max & 6 & & & 5 & & \\
\hline Observations per group: average & 5.571 & & & 4.905 & & \\
\hline N. of Instruments & 39 & & & 38 & & \\
\hline$P$ value of $A R(1)$ Test & 0.803 & & & 0.202 & & \\
\hline$P$ value of $A R(2)$ Test & 0.233 & & & 0.409 & & \\
\hline$P$ value of Sargan Test & 0.879 & & & 0.00500 & & \\
\hline$P$ value of Hansen Test & 0.769 & & & 0.730 & & \\
\hline
\end{tabular}

Consistent with our economic intuition, the regression results in Table 2.2 reveal that countries having stronger trade ties with China receive larger and significant influence from China's growth. Specifically, the growth coefficient of China's GDP per capita implies: if Chinese economy slows down by one-percent, SSA countries are subject to 0.02 percent growth loss while keeping all other factors unchanged. Oil exporters' growth benefits more from China's growth compared to the other two types of countries, which is possibly because China is an important marginal buyer in the global oil market, playing a disproportionately large role in affecting global oil prices. Thus, these channels jointly amplify China's impacts on oil exporters in SSA. 


\begin{tabular}{|c|c|c|c|c|c|c|}
\hline \multirow{4}{*}{$\begin{array}{l}\text { State Variable } \\
1 / 3^{*} \operatorname{Ln}(\text { GDP per capita of each SSA country) }(-3)\end{array}$} & \multicolumn{3}{|c|}{ Strong vs Weak ties with China } & \multicolumn{3}{|c|}{$\begin{array}{l}\text { Oil exporters } \\
\text { vs other resource-intensive exports } \\
\text { vs non-resource-intensive SSAs }\end{array}$} \\
\hline & Coef. & P-value & & Coef. & P-value & \\
\hline & & & & & & \\
\hline & $0.570^{* * *}$ & 0.000 & (4.84) & $0.545^{* * *}$ & 0.000 & (4.23) \\
\hline \multicolumn{7}{|l|}{ Trade Parters' Growth } \\
\hline China's GDP per capita, Growth, for Countries with Strong Ties to China & $0.0161^{* * *}$ & 0.009 & (2.60) & & & \\
\hline China's GDP per capita, Growth, for Countries with W Weak Ties to China & 0.0114 & 0.109 & (1.60) & & & \\
\hline China's GDP per capita, Growth, for Oil Exporters & & & & $0.0349^{* *}$ & 0.043 & (2.02) \\
\hline China's GDP per capita, Growth, for Other Resource-Intensive Countries & & & & $0.0187^{* *}$ & 0.020 & (2.33) \\
\hline China's GDP per capita, Growth, for Non-Resource-Intensive Countries & & & & $0.0188^{* *}$ & 0.042 & $(2.04)$ \\
\hline AE's GDP per capita, Growth & 0.00277 & 0.417 & $(0.81)$ & 0.00621 & 0.186 & (1.32) \\
\hline EM's GDP per capita, Growth & -0.000623 & 0.655 & $(-0.45)$ & -0.00143 & 0.285 & $(-1.07)$ \\
\hline Peer SSA's GDP per capita, Growth & 0.00124 & 0.254 & (1.14) & 0.00136 & 0.277 & (1.09) \\
\hline ROW's GDP per capita, Growth & -0.00158 & 0.386 & $(-0.87)$ & -0.00237 & 0.267 & $(-1.11)$ \\
\hline \multicolumn{7}{|l|}{ Other Variables } \\
\hline Investment-to-GDP ratio & -0.000286 & 0.787 & $(-0.27)$ & 0.000140 & 0.891 & (0.14) \\
\hline Government-Consumption-to-GDP ratio & -0.000303 & 0.842 & $(-0.20)$ & 0.000492 & 0.727 & $(0.35)$ \\
\hline M2-to-GDP ratio & -0.000511 & 0.580 & $(-0.55)$ & -0.000946 & 0.338 & $(-0.96)$ \\
\hline Headline Inflation & -0.000211 & 0.131 & $(-1.51)$ & -0.000206 & 0.146 & $(-1.45)$ \\
\hline Openness & -0.0000978 & 0.797 & $(-0.26)$ & -0.000272 & 0.511 & $(-0.66)$ \\
\hline TOT, change rate & 0.0000755 & 0.766 & $(0.30)$ & 0.000125 & 0.547 & $(0.60)$ \\
\hline N. of Observations & \multicolumn{2}{|l|}{206} & \multicolumn{4}{|c|}{206} \\
\hline N. of Groups & \multicolumn{2}{|l|}{$\begin{array}{r}42 \\
3\end{array}$} & \multirow{2}{*}{\multicolumn{4}{|c|}{$\begin{array}{r}42 \\
3\end{array}$}} \\
\hline Observations per group: min & \multirow{2}{*}{\multicolumn{2}{|c|}{$\begin{array}{l}3 \\
5\end{array}$}} & & 3 & & \\
\hline Observations per group: $\max$ & & & \multicolumn{4}{|c|}{5} \\
\hline Observations per group: average & \multicolumn{2}{|l|}{4.905} & \multicolumn{4}{|c|}{4.905} \\
\hline N. of Instruments & \multicolumn{2}{|l|}{38} & \multicolumn{4}{|c|}{38} \\
\hline$P$ value of $A R(1)$ Test & \multirow{2}{*}{\multicolumn{2}{|c|}{$\begin{array}{l}0.188 \\
0.407\end{array}$}} & \multicolumn{4}{|c|}{0.103} \\
\hline$P$ value of $A R(2)$ Test & & & \multirow{2}{*}{\multicolumn{4}{|c|}{$\begin{array}{r}0.18 \\
0.0124\end{array}$}} \\
\hline P value of Sargan Test & \multicolumn{2}{|l|}{0.00403} & & 0.0124 & & \\
\hline$P$ value of Hansen Test & \multicolumn{2}{|l|}{0.694} & \multicolumn{4}{|c|}{0.518} \\
\hline
\end{tabular}

As Table 2.3 shows, net commodity exporters display stronger dependency on China's growth, illustrating China's strong influence in global commodity markets. If we break down commodity into investment-goods and consumption-goods, columns two and three re-confirm that China's spillover effect is mainly through strong demand on investment-goods. The second column in Table 2.3 shows net-investment-goods exporters have large coefficient relative to the rest SSAs. When we single out net-consumption-goods exporters and conduct the regression, results show that this type of countries experiences relatively small impacts from China, lower than all the rest of SSA countries. All these evidence points to one fact: the main transmission channel of China's economic engagement with SSA is through trade in investment goods and oil.

Guided by the regression outcome above, this paper explores deeper channels of China's impacts by replacing China's growth with its two main components: growth rates of consumption per capita and investment per capita. Table 2.4 shows that countries with strong ties with China receive significant impacts from China's investment growth while countries with weak ties is more likely to get significant impacts through China's consumption growth. Additionally, the third column shows that net-investment-goods exporters experience larger spillover effects stemming from China's investment growth, whereas all other SSA countries are subject to China's impacts also through China's consumption growth. 


\begin{tabular}{|c|c|c|c|c|c|c|c|c|c|}
\hline \multirow{3}{*}{ State Variable } & \multicolumn{3}{|c|}{$\begin{array}{l}\text { Net commodity exporters } \\
\text { vs other SSA countries }\end{array}$} & \multicolumn{3}{|c|}{$\begin{array}{l}\text { Net investment-goods exporters } \\
\text { vs other SSA countries }\end{array}$} & \multicolumn{3}{|c|}{$\begin{array}{l}\text { Net consumption-goods exporters } \\
\text { vs other SSA countries }\end{array}$} \\
\hline & Coef. & P-value & & Coef. & P-value & & Coef. & P-value & \\
\hline & $0.577^{* * *}$ & 0.000 & $(5.10)$ & $0.584^{* * *}$ & 0.000 & $(5.32)$ & $0.583^{* * *}$ & 0.000 & $(4.94)$ \\
\hline \multicolumn{10}{|l|}{ Trade Parters' Growth } \\
\hline China's GDP per capita, Growth, for Net-Commodity Exporters & $0.0171^{* * *}$ & 0.010 & (2.59) & & & & & & \\
\hline China's GDP per capita, Growth, for SSA Excluding net Commodity Exporters & $0.0115^{* *}$ & 0.035 & (2.11) & & & & & & \\
\hline China's GDP per capita, Growth, for Net Investment-goods Exporters & & & & $0.0219^{* *}$ & 0.013 & $(2.48)$ & & & \\
\hline China's GDP per capita, Growth, for SSA Excluding Net Investment-goods Exporters & & & & $0.0135 * *$ & 0.016. & (2.41) & & & \\
\hline China's GDP per capita, Growth, for Net Consumption-goods Exporters & & & & & & & 0.0123 & 0.200 & (1.28) \\
\hline China's GDP per capita, Growth, for SSA Excluding Net Consumption-goods Exporters & & & & & & & $0.0203^{*}$ & .0 .086 & $(1.72)$ \\
\hline AE's GDP per capita, Growth & 0.00367 & 0.283 & $(1.07)$ & 0.00509 & 0.181 & $(1.34)$ & 0.00555 & 0.285 & $(1.07)$ \\
\hline EM's GDP per capita, Growth & -0.000430 & 0.737 & $(-0.34)$ & -0.000952 & 0.423 & $(-0.80)$ & -0.0000713 & 0.963 & $(-0.05)$ \\
\hline Peer SSA's GDP per capita, Growth & 0.00128 & 0.252 & $(1.15)$ & 0.00120 & 0.270 & $(1.10)$ & 0.00103 & 0.362 & $(0.91)$ \\
\hline ROW's GDP per capita, Growth & -0.00157 & 0.386 & $(-0.87)$ & -0.00158 & 0.389 & $(-0.86)$ & -0.00182 & 0.353 & $(-0.93)$ \\
\hline \multicolumn{10}{|l|}{ Other Variables } \\
\hline Investment-to-GDP ratio & -0.000421 & 0.687 & $(-0.40)$ & -0.000350 & 0.738 & $(-0.33)$ & -0.000201 & 0.842 & $(-0.20)$ \\
\hline Government-Consumption-to-GDP ratio & -0.000203 & 0.891 & $(-0.14)$ & -0.0000798 & 0.955 & $(-0.06)$ & -0.000426 & 0.795 & $(-0.26)$ \\
\hline M2-to-GDP ratio & -0.000607 & 0.514 & $(-0.65)$ & -0.000553 & 0.560 & $(-0.58)$ & -0.000489 & 0.648 & $(-0.46)$ \\
\hline Headline Inflation & $-0.000239^{*}$ & 0.069 & $(-1.82)$ & $-0.000234^{*}$ & 0.060 & $(-1.88)$ & -0.000229 & 0.116 & $(-1.57)$ \\
\hline Openness & -0.0000805 & 0.825 & $(-0.22)$ & -0.000117 & 0.756 & $(-0.31)$ & -0.000184 & 0.592 & $(-0.54)$ \\
\hline TOT, change rate & 0.0000926 & 0.671 & $(0.42)$ & 0.0000903 & 0.655 & $(0.45)$ & 0.000229 & 0.386 & $(0.87)$ \\
\hline N. of Observations & 206 & & & 206 & & & 206 & & \\
\hline N. of Groups & 42 & & & 42 & & & 42 & & \\
\hline Observations per group: $\mathrm{min}$ & 3 & & & 3 & & & 3 & & \\
\hline Observations per group: $\max$ & 5 & & & 5 & & & 5 & & \\
\hline Observations per group: average & 4.905 & & & 4.905 & & & 4.905 & & \\
\hline N. of Instruments & 38 & & & 38 & & & 38 & & \\
\hline P value of AR(1) Test & 0.129 & & & 0.106 & & & 0.264 & & \\
\hline P value of $A R(2)$ Test & 0.362 & & & 0.297 & & & 0.457 & & \\
\hline P value of Sargan Test & 0.00643 & & & 0.00979 & & & 0.00634 & & \\
\hline P value of Hansen Test & 0.585 & & & 0.593 & & & 0.793 & & \\
\hline
\end{tabular}

One robust finding for all SSA countries is that GDP per capita is significant across all equation set-ups, implying the importance of the initial level of physical capital on SSA's growth, which indicates the absorptive capacity of the host country. 


\begin{tabular}{|c|c|c|c|c|c|c|c|c|c|}
\hline \multirow{2}{*}{$\begin{array}{l}\text { State Variable: } \\
1 / 3^{*} \operatorname{Ln}(\text { GDP per capita of each SSA country) }(-3)\end{array}$} & \multicolumn{3}{|c|}{ Strong vs Weak ties with China } & \multicolumn{3}{|c|}{$\begin{array}{l}\text { Oil exporters } \\
\text { vs other resource-intensive exports } \\
\text { vs non-resource-intensive SSAs }\end{array}$} & \multicolumn{3}{|c|}{$\begin{array}{l}\text { Net investment-goods exporters } \\
\text { vs other SSA countries }\end{array}$} \\
\hline & $\begin{array}{l}\text { Coef. } \\
\qquad .587^{* * *}\end{array}$ & 0.000 & (5.21) & $0.521^{* * *}$ & 0.000 & (3.70) & $0.622^{* * *}$ & 0.000 & (5.95) \\
\hline \multicolumn{10}{|l|}{ Trade Parters' Growth } \\
\hline China's Consumption per capita, Growth, for Countries with Strong Ties to China & 0.00443 & 0.486 & (0.70) & & & & & & \\
\hline China's Investment per capita, Growth, for Countries with Strong Ties to China & $0.0100^{*}$ & 0.073 & (1.79) & & & & & & \\
\hline China's Investment per capita, Growth, for Countries with Weak Ties to China & 0.00701 & 0.224 & (1.21) & & & & & & \\
\hline China's Consumption per capita, Growth, for Oil Exporters & & & & 0.0175 & 0.156 & (1.42) & & & \\
\hline China's Consumption per capita, Growth, for Other Resource-Intensive Countries & & & & 0.00268 & 0.687 & $(0.40)$ & & & \\
\hline China's Consumption per capita, Growth, for Non-Resource-Intensive Countries & & & & $0.0119^{*}$ & 0.085 & (1.72) & & & \\
\hline China's Investment per capita, Growth, for Oil Exporters & & & & 0.0196 & 0.117 & (1.57) & & & \\
\hline China's Investment per capita, Growth, for Other Resource-Intensive Countries & & & & 0.00911 & 0.218 & (1.23) & & & \\
\hline China's Investment per capita, Growth, for Non-Resource-Intensive Countries & & & & 0.0101 & 0.235 & (1.19) & & & \\
\hline China's Consumption per capita, Growth, for Net Investment-goods Exporters & & & & & & & 0.00725 & 0.137 & (1.49) \\
\hline China's Consumption per capita, Growth, for SSA Excluding Net Investment-goods Exporters & & & & & & & $0.00750^{* *}$ & 0.036 & (2.10) \\
\hline China's Investment per capita, Growth, for SSA Excluding Net Investment-goods Exporters. & & & & & & & $0.00586^{*}$ & 0.060 & (1.88) \\
\hline AE's GDP per capita, Growth & 0.00204 & 0.797 & (0.26) & 0.00389 & 0.732 & (0.34) & 0.00457 & 0.207 & (1.26) \\
\hline EM's GDP per capita, Growth & 0.00148 & 0.618 & (0.50) & -0.00160 & 0.560 & $(-0.58)$ & -0.00101 & 0.419 & $(-0.81)$ \\
\hline Peer SSA's GDP per capita, Growth & -0.00216 & 0.579 & $(-0.55)$ & -0.00334 & 0.455 & $(-0.75)$ & 0.000874 & 0.436 & $(0.78)$ \\
\hline ROW's GDP per capita, Growth & -0.00552 & 0.114 & $(-1.58)$ & -0.00428 & 0.173 & $(-1.36)$ & -0.00140 & 0.442 & $(-0.77)$ \\
\hline \multicolumn{10}{|l|}{ Control Variables: } \\
\hline Investment-to-GDP ratio & -0.000399 & 0.687 & $(-0.40)$ & 0.000610 & 0.537 & $(0.62)$ & -0.000259 & 0.793 & $(-0.26)$ \\
\hline Government-Consumption-to-GDP ratio & -0.00122 & 0.525 & $(-0.64)$ & 0.00112 & 0.476 & $(0.71)$ & -0.000246 & 0.858 & $(-0.18)$ \\
\hline M2-to-GDP ratio & -0.000536 & 0.424 & $(-0.80)$ & $-0.00147^{*}$ & 0.056 & $(-1.91)$ & -0.000348 & 0.726 & $(-0.35)$ \\
\hline Headline Inflation & -0.000267 & 0.120 & $(-1.55)$ & $-0.000411^{* * *}$ & 0.003 & $(-2.99)$ & $-0.000268^{* *}$ & 0.018 & $(-2.37)$ \\
\hline Openness & 0.0000898 & 0.853 & $(0.19)$ & -0.000406 & 0.481 & $(-0.70)$ & -0.0000221 & 0.959 & $(-0.05)$ \\
\hline TOT, change rate & 0.000488 & 0.383 & $(0.87)$ & 0.0000452 & 0.914 & $(0.11)$ & 0.000164 & 0.487 & $(0.70)$ \\
\hline N. of Observations & 206 & & & 206 & & & 206 & & \\
\hline N. of Groups & 42 & & & 42 & & & 42 & & \\
\hline Observations per group: $\mathrm{min}$ & 3 & & & 3 & & & 3 & & \\
\hline Observations per group: $\max$ & 5 & & & 5 & & & 5 & & \\
\hline Observations per group: average & 4.905 & & & 4.905 & & & 4.905 & & \\
\hline N. of Instruments & 38 & & & 38 & & & 38 & & \\
\hline$P$ value of Hansen Test & 0.695 & & & 0.691 & & & 0.862 & & \\
\hline
\end{tabular}

\section{SSA' Goods Exports to the World}

This subsection focuses on the role of China's economy on SSA's total exports. SSA countries are price-takers at the global commodity markets and export volumes are largely driven by external shocks to demands and prices. Therefore, the regression equation ${ }^{11}$ includes both trade partners' growth and variables related to prices and exchange rates, namely inflation, NEER and Terms of Trade although abstracting from institutional and policy variables. One important feature of the regression is to add the variable of exports to China, which is used to proxy for a potential channel for China's impacts to SSAs. In addition, logged GDP per capita and population growth are added to control for country's development stage and demographic effect. Given the assumption that SSA exports are mainly driven by external factors, endogeneity issues could be reasonably argued away or mitigated to a lesser degree. For example, inflation may impact the costs of exporting companies while it is less possible that exports can have a significant impact on the general domestic price level. For NEER's

${ }^{11}$ The set-up follows equation (4), using annul data from 2003 to 2015. 
endogeneity, regression without NEER is conducted and the results are similar to that with NEER, helping ensure that the impact of endogeneity is marginal if any.

The regression results confirm the notion that exports to China significantly contribute to total exports growth of countries either having strong ties with China or defined as resource-intensive or net-commodity exporters.

In Table 3.1, the first regression with only trade partner's growth shows significance of exports to China. To check the missing-variable bias, the second regression adds more control variables, but the significance of exports to China remains except for a small change in the magnitude.

When countries are divided by trade ties with China, it is intuitive to see countries with strong ties have a significant and higher coefficient of exports to China (Table 3.2). In contrast, exports of countries with weak ties are influenced significantly by TOT.

Resource-intensive countries are made up of oil exporters and other resource-intensive exporters as IMF (2017). Results recorded in Table 3.3 show a notable impact of exports to China on total exports of resource-intensive exports.

Regressions with different types of net commodity exporters (Table 3.4) show that exports to China can be a significant indicator for total exports of net investment-goods and net consumption-goods countries. China's growth plays a significantly positive effect on the exports of both types of countries while changes in NEER is negatively related to exports.

These regressions help identify the possible transmission mechanisms of China's growth to SSA. Exports to China is a good indicator of SSA's total exports, which constitute an important component of GDP. When China's economy shifts from investment-driven to consumptiondriven model, the scale of its impacts on SSA exports and growth depend on the channel of exports to China, which motivates a deeper examination of the determinants of exports to China. 


\begin{tabular}{|c|c|c|c|c|}
\hline \multirow[b]{2}{*}{ Goods exports to China, Growth } & \multicolumn{2}{|c|}{ All ( eq 1) } & \multicolumn{2}{|c|}{ All (eq 2) } \\
\hline & $0.126^{* *}$ & (2.20) & $0.124^{* *}$ & (2.20) \\
\hline \multicolumn{5}{|l|}{ Trade Parters' Growth } \\
\hline China's GDP, Growth & 3.022 & (1.62) & 2.470 & (1.09) \\
\hline AE's GDP, Growth & 0.140 & $(0.08)$ & 0.118 & $(0.07)$ \\
\hline EM's GDP, Growth & 2.537 & (1.31) & 2.456 & (1.17) \\
\hline Peer SSA's GDP, Growth & -0.875 & $(-1.21)$ & -0.442 & $(-0.55)$ \\
\hline ROW's GDP, Growth & 0.883 & (1.34) & 0.630 & $(1.07)$ \\
\hline \multicolumn{5}{|l|}{ Other Variables } \\
\hline Headline Inflation, in percent & & & -0.290 & $(-0.46)$ \\
\hline NEER, in percentage change & & & -0.552 & $(-1.59)$ \\
\hline TOT, in percentage change & & & 0.147 & (1.30) \\
\hline Population, in percentage change & & & $13.03^{* *}$ & (2.05) \\
\hline Ln( GDP per capita of each SSA country) & & & 7.251 & $(0.36)$ \\
\hline Constant & $-38.26 *$ & $(-1.82)$ & -119.3 & $(-0.77)$ \\
\hline R2 & 0.116 & & 0.142 & \\
\hline N. of Observations & 310 & & 301 & \\
\hline N. of Groups & 33 & & 32 & \\
\hline Observations per group: min & 2 & & 2 & \\
\hline Observations per group: $\max$ & 13 & & 13 & \\
\hline Observations per group: average & 9.394 & & 9.406 & \\
\hline
\end{tabular}

\begin{tabular}{|c|c|c|c|c|}
\hline \multirow{2}{*}{ Goods exports to China, Growth } & \multicolumn{2}{|c|}{ Strong Ties with China } & \multicolumn{2}{|c|}{ Weak Ties with China } \\
\hline & $0.174^{* *}$ & (2.22) & 0.00842 & $(0.38)$ \\
\hline \multicolumn{5}{|l|}{ Trade Parters' Growth } \\
\hline China's GDP, Growth & 3.138 & (1.19) & -0.643 & $(-0.14)$ \\
\hline AE's GDP, Growth & 0.506 & $(0.16)$ & 0.988 & $(0.48)$ \\
\hline EM's GDP, Growth & 4.366 & (1.26) & 1.115 & $(0.69)$ \\
\hline Peer SSA's GDP, Growth & -0.268 & $(-0.22)$ & -0.888 & $(-0.60)$ \\
\hline ROW's GDP, Growth & 0.146 & $(0.24)$ & 1.469 & $(1.24)$ \\
\hline \multicolumn{5}{|l|}{ Other Variables } \\
\hline Headline Inflation, in percent & -1.301 & $(-1.15)$ & $1.181^{*}$ & (1.98) \\
\hline NEER, in percentage change & -0.848 & $(-1.69)$ & 0.213 & $(0.61)$ \\
\hline $\mathrm{TOT}$, in percentage change & -0.0193 & $(-0.15)$ & $0.289 * *$ & (2.24) \\
\hline Population, in percentage change & 12.31 & $(1.39)$ & 5.082 & $(0.46)$ \\
\hline $\operatorname{Ln}($ GDP per capita of each SSA country) & -2.359 & $(-0.09)$ & -24.36 & $(-0.95)$ \\
\hline Constant & -66.36 & $(-0.34)$ & 150.8 & $(0.69)$ \\
\hline R2 & 0.196 & & 0.244 & \\
\hline N. of Observations & 193 & & 108 & \\
\hline N. of Groups & 19 & & 13 & \\
\hline Observations per group: $\min$ & 5 & & 2 & \\
\hline Observations per group: $\max$ & 13 & & 13 & \\
\hline Observations per group: average & 10.16 & & 8.308 & \\
\hline
\end{tabular}

\section{CInternational Monetary Fund. Not for Redistribution}




\begin{tabular}{|c|c|c|c|c|}
\hline \multirow[b]{2}{*}{ Goods exports to China, Growth } & \multicolumn{2}{|c|}{ Resource-Intensive Exporters } & \multicolumn{2}{|c|}{ Non-Resource-Intensive Exporters } \\
\hline & $0.118^{* *}$ & (2.66) & 0.134 & (0.94) \\
\hline \multicolumn{5}{|l|}{ Trade Parters' Growth } \\
\hline China's GDP, Growth & 4.090 & (1.59) & 1.183 & $(0.31)$ \\
\hline AE's GDP, Growth & -4.219 & $(-1.60)$ & 1.844 & $(0.60)$ \\
\hline EM's GDP, Growth & -0.329 & $(-0.42)$ & 6.938 & (1.31) \\
\hline Peer SSA's GDP, Growth & -0.274 & $(-0.32)$ & -1.407 & $(-0.99)$ \\
\hline ROW's GDP, Growth & 0.552 & $(1.03)$ & -0.746 & $(-0.36)$ \\
\hline \multicolumn{5}{|l|}{ Other Variables } \\
\hline Headline Inflation, in percent & 0.202 & (0.56) & 0.0687 & $(0.06)$ \\
\hline NEER, in percentage change & -0.363 & $(-1.49)$ & -1.041 & $(-1.02)$ \\
\hline TOT, in percentage change & -0.0676 & $(-0.66)$ & 0.107 & $(0.44)$ \\
\hline Population, in percentage change & $21.58^{* * *}$ & (3.25) & 27.37 & (1.23) \\
\hline $\operatorname{Ln}($ GDP per capita of each SSA country) & 21.02 & $(0.77)$ & 9.077 & (0.19) \\
\hline Constant & -237.8 & $(-1.14)$ & -179.9 & $(-0.48)$ \\
\hline R2 & 0.380 & & 0.209 & \\
\hline N. of Observations & 165 & & 136 & \\
\hline N. of Groups & 18 & & 14 & \\
\hline Observations per group: min & 2 & & 4 & \\
\hline Observations per group: $\max$ & 13 & & 13 & \\
\hline Observations per group: average & 9.167 & & 9.714 & \\
\hline
\end{tabular}

\begin{tabular}{|c|c|c|c|c|c|c|}
\hline \multirow[b]{2}{*}{ Goods exports to China, Growth } & \multicolumn{2}{|c|}{ Investment-Goods Exporters } & \multicolumn{2}{|c|}{ Consumption-Goods Exporters } & \multicolumn{2}{|c|}{ Non-Net-Commodity Exporters } \\
\hline & $0.127^{* *}$ & (2.83) & $0.0868^{*}$ & (2.06) & 0.326 & (1.34) \\
\hline \multicolumn{7}{|l|}{ Trade Parters' Growth } \\
\hline China's GDP, Growth & $5.513^{* *}$ & (2.42) & $6.273^{* *}$ & (2.90) & -2.162 & $(-0.16)$ \\
\hline AE's GDP, Growth & -2.102 & $(-0.86)$ & $8.917^{*}$ & (2.13) & -0.201 & $(-0.07)$ \\
\hline EM's GDP, Growth & -0.721 & $(-0.75)$ & -1.369 & $(-1.00)$ & 7.769 & (1.16) \\
\hline Peer SSA's GDP, Growth & -1.144 & $(-1.68)$ & -0.395 & $(-0.20)$ & -0.659 & $(-0.30)$ \\
\hline ROW's GDP, Growth & 0.620 & (1.21) & $-1.904^{*}$ & $(-2.22)$ & 3.290 & (1.41) \\
\hline \multicolumn{7}{|l|}{ Other Variables } \\
\hline Headline Inflation, in percent & 0.496 & $(0.63)$ & -0.996 & $(-1.21)$ & -1.881 & $(-1.18)$ \\
\hline NEER, in percentage change & $-0.760^{* *}$ & $(-2.72)$ & $-0.669^{*}$ & $(-1.99)$ & -0.489 & $(-0.74)$ \\
\hline TOT, in percentage change & 0.119 & (1.19) & -0.0751 & $(-0.36)$ & 0.279 & $(0.96)$ \\
\hline Population, in percentage change & $19.74^{* * * *}$ & $\begin{array}{l}\text { (3.16) } \\
\text { (1) }(3)\end{array}$ & 5.565 & $(0.28)$ & 67.33 & (1.29) \\
\hline Ln( GDP per capita of each SSA country) & 30.78 & $\begin{array}{l}3.10) \\
(1.03)\end{array}$ & $\begin{array}{l}-11.03 \\
-11.09\end{array}$ & $(-0.30)$ & 17.71 & $\begin{array}{l}1.297) \\
(0.17)\end{array}$ \\
\hline Constant & -315.5 & $(-1.42)$ & 12.62 & $(0.06)$ & -310.1 & $(-0.33)$ \\
\hline R2 & 0.440 & & 0.260 & & 0.340 & \\
\hline N. of Observations & 148 & & 94 & & 75 & \\
\hline N. of Groups & 17 & & 9 & & 8 & \\
\hline Observations per group: $\min$ & 2 & & 6 & & 6 & \\
\hline Observations per group: $\max$ & 13 & & 13 & & 13 & \\
\hline Observations per group: average & 8.706 & & 10.44 & & 9.375 & \\
\hline
\end{tabular}

\section{SSA’ Goods Exports to China}

Given this subsection focuses on the determinants of exports to China, it is natural to keep only China's growth while excluding other trading partners'. As explained in the section of Data and Methods, China's FDI is introduced to control for economic relations with China. As it takes time to transform investment into production capacity for exports, China's FDI is expected to take effect with one-year lag.

Results in Table 4.1 confirm the notion that exports to China is subject to China's GDP growth. Specifically, a one-percent GDP growth in China brings SSA goods exports to China a 23 percent increase, which is quite substantial and stable under different regression specifications. In addition, GDP per capita as a proxy for productivity and technological absorption is constantly significant in regression, implying that the initial capital conditions are crucial for SSA exporting countries to integrate into the Chinese trade value chain. When local employees 
occupy certain level of skills and productivity (which guarantees goods quality), the host country becomes more attractive for China's global purchase. As Table 4.1 shows, the negative coefficient of inflation reveals that price spikes increase exporters' cost relative to other global suppliers in real terms, reducing its price competitiveness and ultimately its export volume.

\begin{tabular}{|c|c|c|c|c|c|c|c|c|}
\hline \multirow[b]{2}{*}{ China's GDP, Growth } & \multicolumn{2}{|c|}{ All ( eq 1) } & \multicolumn{2}{|c|}{ All (eq 2) } & \multicolumn{2}{|c|}{ All ( eq 3) } & \multicolumn{2}{|c|}{ All (eq 4) } \\
\hline & $18.50^{* * *}$ & (3.02) & $23.27 * * *$ & (3.79) & $23.09 * * *$ & (3.76) & $23.01 * * *$ & (3.81) \\
\hline China's FDI to each SSA country(-1) & 0.151 & $(0.67)$ & -0.0379 & $(-0.15)$ & -0.0486 & $(-0.19)$ & -0.0404 & $(-0.15)$ \\
\hline Ln( GDP per capita of each SSA country) & & & $143.6^{* * *}$ & (3.07) & $146.3^{* * *}$ & (3.16) & $148.3^{* * *}$ & (3.23) \\
\hline Headline Inflation, in percent & & & -1.447 & $(-1.63)$ & $-1.769 *$ & $(-1.75)$ & $-1.758^{*}$ & $(-1.73)$ \\
\hline NEER, in percentage change & & & & & -0.470 & $(-0.76)$ & -0.455 & $(-0.74)$ \\
\hline TOT, in percentage change & & & 0.0555 & $(0.21)$ & 0.0578 & $(0.21)$ & 0.0517 & $(0.19)$ \\
\hline Population, in percentage change & & & & & & & 10.45 & $(0.38)$ \\
\hline Constant & $-126.5^{* *}$ & $(-2.52)$ & $-1144.8^{* * *}$ & $(-3.41)$ & $-1161.1^{* * *}$ & $(-3.49)$ & $-1202.4^{* * *}$ & $(-3.82)$ \\
\hline R2 & 0.0813 & & 0.119 & & 0.121 & & 0.122 & \\
\hline N. of Observations & 242 & & 237 & & 237 & & 237 & \\
\hline N. of Groups & 33 & & 32 & & 32 & & 32 & \\
\hline Observations per group: $\mathrm{min}$ & 1 & & 1 & & 1 & & 1 & \\
\hline Observations per group: $\max$ & 12 & & 12 & & 12 & & 12 & \\
\hline Observations per group: average & 7.333 & & 7.406 & & 7.406 & & 7.406 & \\
\hline
\end{tabular}

As Table 4.2 presents, country heterogeneity is influential in determining China's impacts on exports to China. For example, countries with strong trade ties with China have a significant and higher coefficient for China's growth compared to those with weak trade ties. Also, China's spillover effect is stronger in resource-intensive exporting countries than in other SSA countries, which could be linked to trade structures between China and SSA and the way how China has strengthened its economic engagement with SSA. Interestingly, Table 4.2 also shows that no matter which group of the country, GDP per capita is a robust factor to boost exports to China: a one-percent increase in GDP per capita increases the growth rate of goods-exports-toChina by more than one percent.

The two tables show that China's growth matters for exports to China. A related question is which of its components really matter: consumption or investment growth or both? Table 4.3 shows that China's consumption has negative spillover on SSA's exports to China while its investment has positive effects. For example, countries with strong trade ties to China benefit from positive influence of China's investment growth. By contrast, countries with weak ties may suffer significantly from China's consumption growth. 


\begin{tabular}{|c|c|c|c|c|c|c|c|c|}
\hline \multirow[b]{2}{*}{ China's GDP, Growth } & \multicolumn{2}{|c|}{ Strong Ties with China } & \multicolumn{2}{|c|}{ Weak Ties with China } & \multicolumn{2}{|c|}{ Resource-Intensive Exporters } & \multicolumn{2}{|c|}{ Non-Resource-Intensive Exporters } \\
\hline & $24.99 * * *$ & (3.26) & 22.60 & (1.43) & $25.89^{* *}$ & (2.45) & $17.94^{*}$ & (1.85) \\
\hline China's FDI to each SSA country(-1) & 0.0339 & $(0.09)$ & -0.103 & $(-0.35)$ & -0.0107 & $(-0.02)$ & 0.0296 & $(0.09)$ \\
\hline Ln( GDP per capita of each SSA country) & $144.3^{* *}$ & (2.19) & $200.5^{*}$ & (2.12) & $138.6^{*}$ & (1.94) & $140.0^{* *}$ & $(2.79)$ \\
\hline Headline Inflation, in percent & -0.814 & $(-0.54)$ & $-3.290^{*}$ & $(-2.08)$ & -1.689 & $(-1.20)$ & -0.515 & $(-0.28)$ \\
\hline NEER, in percentage change & -0.0178 & $(-0.02)$ & -1.373 & $(-1.29)$ & -1.207 & $(-1.15)$ & 0.231 & (0.26) \\
\hline TOT, in percentage change & 0.118 & (0.34) & -0.293 & $(-0.81)$ & 0.296 & (0.74) & $-0.477^{*}$ & $(-1.79)$ \\
\hline Population, in percentage change & 3.444 & $(0.12)$ & 47.23 & (0.93) & 7.558 & $(0.28)$ & 37.28 & $(0.90)$ \\
\hline Constant & $-1176.3^{* *}$ & $(-2.68)$ & $-1638.8^{*}$ & $(-1.93)$ & $-1189.0^{* *}$ & $(-2.54)$ & $-1144.8^{* *}$ & $(-2.96)$ \\
\hline R2 & 0.143 & & 0.224 & & 0.208 & & 0.153 & \\
\hline N. of Observations & 150 & & 87 & & 116 & & 121 & \\
\hline N. of Groups & 19 & & 13 & & 18 & & 14 & \\
\hline Observations per group: $\mathrm{min}$ & 3 & & 1 & & 1 & & 4 & \\
\hline Observations per group: $\max$ & 12 & & 11 & & 12 & & 12 & \\
\hline Observations per group: average & 7.895 & & 6.692 & & 6.444 & & 8.643 & \\
\hline
\end{tabular}

\begin{tabular}{|c|c|c|c|c|c|c|c|c|c|c|}
\hline \multirow[b]{2}{*}{ China's Consumption, Growth } & \multicolumn{2}{|c|}{ All } & \multicolumn{2}{|c|}{ Strong Ties with China } & \multicolumn{2}{|c|}{ Weak Ties with China } & \multicolumn{2}{|c|}{ Resource-Intensive Exporters } & \multicolumn{2}{|c|}{ Non-Resource-Intensive Exporters } \\
\hline & $-35.59^{*}$ & $(-1.74)$ & -16.92 & $(-0.59)$ & $-60.55^{*}$ & $(-1.89)$ & $-45.97^{*}$ & $(-1.94)$ & -27.55 & $(-0.87)$ \\
\hline China's Investment, Growth & $5.074^{*}$ & (1.91) & $7.098^{* *}$ & (2.39) & 3.118 & (0.48) & 5.277 & $(1.33)$ & 3.972 & (1.04) \\
\hline China's FDI to each SSA country(-1) & -0.0404 & $(-0.15)$ & 0.0339 & $(0.09)$ & -0.103 & $(-0.35)$ & -0.0107 & $(-0.02)$ & 0.0296 & $(0.09)$ \\
\hline Ln( GDP per capita of each SSA country) & $148.3^{* * *}$ & (3.23) & $144.3^{* *}$ & (2.19) & $200.5^{*}$ & (2.12) & $138.6^{*}$ & (1.94) & $140.0^{* *}$ & (2.79) \\
\hline Headline Inflation, in percent & $-1.758^{*}$ & $(-1.73)$ & -0.814 & $(-0.54)$ & $-3.290^{*}$ & $(-2.08)$ & -1.689 & $(-1.20)$ & -0.515 & $(-0.28)$ \\
\hline NEER, in percentage change & -0.455 & $(-0.74)$ & -0.0178 & $(-0.02)$ & -1.373 & $(-1.29)$ & -1.207 & $(-1.15)$ & 0.231 & (0.26) \\
\hline TOT, in percentage change & 0.0517 & $(0.19)$ & 0.118 & $(0.34)$ & -0.293 & $(-0.81)$ & 0.296 & $(0.74)$ & $-0.477^{*}$ & $(-1.79)$ \\
\hline Population, in percentage change & 10.45 & $(0.38)$ & 3.444 & $(0.12)$ & 47.23 & $(0.93)$ & 7.558 & $(0.28)$ & 37.28 & $(0.90)$ \\
\hline Constant & $-779.3^{* *}$ & $(-2.12)$ & -906.7 & $(-1.70)$ & -999.3 & $(-1.09)$ & -660.9 & $(-1.19)$ & $-816.6^{*}$ & $(-2.03)$ \\
\hline R2 & 0.122 & & 0.143 & & 0.224 & & 0.208 & & 0.153 & \\
\hline N. of Observations & 237 & & 150 & & 87 & & 116 & & 121 & \\
\hline N. of Groups & 32 & & 19 & & 13 & & 18 & & 14 & \\
\hline Observations per group: $\mathrm{min}$ & 1 & & 3 & & 1 & & 1 & & 4 & \\
\hline Observations per group: $\max$ & 12 & & 12 & & 11 & & 12 & & 12 & \\
\hline Observations per group: average & 7.406 & & 7.895 & & 6.692 & & 6.444 & & 8.643 & \\
\hline
\end{tabular}

\section{CONCLUSION}

From the above empirical analysis, we can draw the following conclusions: (i) after China's entrance into the WTO in December 2001, its economic impacts on SSA economies have grown significantly: a one-percent increase in China's GDP per capita leads to the 0.02percent increase of SSA's GDP per capita; by contrast, Advanced Economies, Emerging Markets, and peer SSAs, although exerting positive influences, do not play such a significant role in affecting the SSA countries; (ii) Country heterogeneity helps shape the dependence of SSA on China's growth, specifically, oil and investment-goods exporters benefit more from China's growth; (iii) compared to China's consumption, its investment growth acts as a more important channel influencing SSA; (iv) exports to China, highly linked to China's growth, is an crucial indicator for SSA's exports. 
Given the growing influence of China's economy on SSA countries, it is urgent for SSA countries to be well prepared to better take advantage of China's rebalancing and successfully integrate into the world value chain for industrial upgrading.

One prominent feature of China's economic rebalancing is to move from an investmentdriven to a consumption-driven growth. Although our results reveal that consumption growth may have negative impacts on SSA' exports, this effect could be changed with export diversification strategies. For example, companies in non-resource-intensive countries can follow China's consumption trend and meet its increasing consumption demand by planting specific cash crops such as cotton and coffee. SSA resource-intensive exporters should try to move towards a diversified and inclusive growth model and reduce their reliance on nonrenewable commodities.

One purpose of China's economic rebalancing is to upgrade its own industrial structure by outsourcing its lower-end industries to other countries with adequate production capacity. SSA countries could proactively improve business environment to compete for the outsourcing business from Chinese companies.

Meanwhile, China's rebalancing also provides new opportunities for SSA countries: firstly, the associated outsourcing process could imply more outward private FDI from China into SSA, helping the host countries accumulate necessary physical and human capital; secondly, China's active public involvement in SSA's infrastructural sectors (especially in energy, railway, and telecommunication) has not declined. This bilateral cooperation can help SSA countries to increase growth potentials by eliminating infrastructure bottlenecks and increase local employment. In this context, resource-rich SSA countries who seek future Chinese investments can continue to tailor their policies towards infrastructural developments and improve business environment.

Overall, there is still huge room for economic and business cooperation between SSA and China going forward. Policies promoting growth diversification and infrastructural development will lead to more win-win deals for both sides. 


\section{REFERENCES}

Arellano, Manuel and Bond, Stephen, 1991. "Some Tests of Specification for Panel Data:

Monte Carlo Evidence and an Application to Employment Equations." Review of Economic Studies, 58, issue 2, p. 277-297.

Arellano, Manuel \& Bover, Olympia, 1995. "Another look at the instrumental variable estimation of error-components models." Journal of Econometrics, vol. 68(1), p. 29-51.

Arora, Vivek, and Athanasios Vamvakidis, 2004. "How Much Do Trading Partners Matter for Economic Growth?" International Monetary Fund Working Paper Series.

Arslanalp, Serkan, Wei Liao, Shi Piao, and Dulani Seneviratne, 2016. "China's Growing Influence on Asian Financial Markets." International Monetary Fund Working Paper Series.

Blagrave, Patrick, and Esteban Vesperoni, 2016. "Spillover Implications of China's Slowdown for International Trade." International Monetary Fund Working Paper Series.

Blundell, Richard, and Stephen Bond, 1998. "Initial Conditions and Moment Restrictions in Dynamic Panel Data Models." Journal of Econometrics 87, p. 115-43.

Borensztein, E., J. De Gregorio, and J-W Lee, 1998. "How Does Foreign Direct Investment Affect Economic Growth?" Journal of International Economics 45, p. 115-35.

Caselli, Francesco, Gerardo Esquivel, and Fernando Lefort, 1996. "Reopening the Convergence Debate: A New Look at Cross-Country Growth Empirics." Journal of Economic Growth.

Cashin, Paul, Kamiar Mohaddes, and Mehdi Raissi, 2016. "China's Slowdown and Global Financial Market Volatility: Is World Losing Out." International Monetary Fund Working Paper Series.

Ceglowski, Janet, Stephen Golub, Aly Mbaye, and Varun Prasad, 2015. "Can Africa Compete with China in Manufacturing? The Role of Relative Unit Labor Costs." International Monetary Fund Working Paper Series.

Chen, Wenjie, and Roger Nord, 2017. "A Rebalancing Act for China and Africa." International Monetary Fund Working Paper Series.

David Roodman, 2009. "How to do xtabond2: An introduction to difference and system GMM in Stata." Stata Journal, vol. 9(1), p. 86-136.

Dizioli, Allan, Jaime Guajardo, Vladimir Klyuev, Rui Mano, and Mehdi Raissi, 2016. "Spillovers from China's Growth Slowdown and Rebalancing to the ASEAN-5 Economies." International Monetary Fund Working Paper Series. 
Edwards, L. and Jenkins, R, 2015. "The Impact of Chinese Import Penetration on the South African Manufacturing Sector." The Journal of Development Studies, 51, p. 320-340.

Holtz-Eakin, Douglas, et al, 1988. "Estimating Vector Autoregressions with Panel Data." Econometrica, vol. 56, no. 6, p. 1371-1395.

Hong, Gee Hee, Jaewoo Lee, Wei Liao, and Dulani Seneviratne, 2016. "China and Asia in Global Trade Slowdown." International Monetary Fund Working Paper Series.

IMF, 2016. "Regional Economic Outlook: Building on Asia's Strengths During Turbulent Times." International Monetary Fund.

IMF, 2017. "Regional Economic Outlook: Restarting the Growth Engine." International Monetary Fund.

Kireyev, Alexei, and Andrei Leonidov, 2016. "China's Imports Slowdown: Spillovers, Spillins, and Spillbacks." International Monetary Fund Working Paper Series.

Kolerus, Christina, Papa N'Diaye, and Christian Saborowski, 2016. "China's Footprint in Global Commodity Markets." International Monetary Fund Working Paper Series.

Levine, Ross, Norman Loayza, and Thorsten Beck, 2000. "Financial Intermediation and Growth: Causality and Causes." Journal of Monetary Economics 46, p. 31-77.

Mwase, Nkunde, Papa N'Diaye, Hiroko Oura, Frantisek Ricka, Katsiaryna Svirydzenka, and Yuanyan Zhang, 2016. "Spillovers from China: Financial Channels." International Monetary Fund Working Paper Series.

Papageorgiou, Chris, and Peichu Xie, 2016. "What Does A Global Economic Slowdown Mean to LIDCs: An Empirical Investigation of Co-movements and Linkages with Trading Partners." International Monetary Fund Working Paper Series. Unpublished. 


\section{APPENDIX}

\begin{tabular}{|c|c|c|c|c|c|}
\hline Advanced Economies $(\mathrm{AE})^{1}$ & Emerging Markets $(E A)^{2}$ & Sub-Saharan Africa (SSA) ${ }^{3}$ & Rest of the World (ROW) & & \\
\hline Australia & Brazil & Angola & Afghanistan, Islamic Republic of & Guatemala & Special Categories \\
\hline Austria & Chile & Benin & Albania & Guyana & Sri Lanka \\
\hline Belgium & Colombia & Botswana & Algeria & Haiti & St. Kitts and Nevis \\
\hline Canada & Egypt & Burkina Faso & American Samoa & Honduras & St. Lucia \\
\hline Cyprus & Hungary & Burundi & Anguilla & Iran, Islamic Republic of & St. Vincent and the Grenadines \\
\hline Czech Republic & India & Cabo Verde & Antigua and Barbuda & Iraq & Sudan \\
\hline Denmark & Indonesia & Cameroon & Argentina & Jamaica & Suriname \\
\hline Estonia & Malaysia & Central African Republic & Armenia, Republic of & Jordan & Syrian Arab Republic \\
\hline Finland & Mexico & Chad & Aruba & Kazakhstan & Tajikistan \\
\hline France & Pakistan & Comoros & Azerbaijan, Republic of & Kiribati & Timor-Leste, Dem. Rep. of \\
\hline Germany & Peru & Congo, Democratic Republic of & Bahamas, The & Kuwait & Tonga \\
\hline Greece & Philippines & Congo, Republic of & Bahrain, Kingdom of & Kyrgyz Republic & Trinidad and Tobago \\
\hline Iceland & Poland & Cote d'Ivoire & Bangladesh & Lao People's Democratic Republic & Tunisia \\
\hline Ireland & Qatar & Equatorial Guinea & Barbados & Lebanon & Turkmenistan \\
\hline Israel & Russian Federation & Eritrea & Belarus & Libya & Tuvalu \\
\hline Italy & Thailand & Ethiopia & Belgium-Luxembourg & Macedonia, FYR & Ukraine \\
\hline Japan & Turkey & Gabon & Belize & Maldives & Uruguay \\
\hline Korea, Republic of & United Arab Emirates & Gambia, The & Bermuda & Marshall Islands, Republic of & Uzbekistan \\
\hline Latvia & & Ghana & Bhutan & Mauritania & Vanuatu \\
\hline Lithuania & & Guinea & Bolivia & Micronesia, Federated States of & Vatican \\
\hline Luxembourg & & Guinea-Bissau & Bosnia and Herzegovina & Moldova & Venezuela, Republica Bolivariana de \\
\hline Malta & & Kenya & Brunei Darussalam & Mongolia & Vietnam \\
\hline Netherlands & & Lesotho & Bulgaria & Montenegro & West Bank and Gaza \\
\hline New Zealand & & Liberia & Cambodia & Montserrat & Yemen, P.D. Rep. \\
\hline Norway & & Madagascar & Costa Rica & Morocco & Yemen, Republic of \\
\hline Portugal & & Malawi & Croatia & Myanmar & Yugoslavia, SFR \\
\hline San Marino & & Mali & Cuba & Nauru & \\
\hline Singapore & & Mauritius & Curacao & Nepal & \\
\hline Slovak Republic & & Mozambique & Czechoslovakia & Netherlands Antilles & \\
\hline Slovenia & & Namibia & Djibouti & French Territories: New Caledonia & \\
\hline Spain & & Niger & Dominica & Nicaragua & \\
\hline Sweden & & Nigeria & Dominican Republic & Korea, Democratic People's Rep. of & \\
\hline Switzerland & & Rwanda & Eastern Germany & Oman & \\
\hline United Kingdom & & Sao Tome and Principe & Ecuador & Palau & \\
\hline \multirow[t]{10}{*}{ United States } & & Senegal & El Salvador & Panama & \\
\hline & & Seychelles & Falkland Islands & Papua New Guinea & \\
\hline & & Sierra Leone & Faroe Islands & Paraguay & \\
\hline & & South Africa & Fiji & Romania & \\
\hline & & Swaziland & French Territories: French Polynesia & Samoa & \\
\hline & & Tanzania & Georgia & Saudi Arabia & \\
\hline & & Togo & Gibraltar & Serbia and Montenegro & \\
\hline & & Uganda & Greenland & Serbia, Republic of & \\
\hline & & Zambia & Grenada & Solomon Islands & \\
\hline & & Zimbabwe & Guam & Somalia & \\
\hline
\end{tabular}

Notes:

1/ The country group of Advanced Economies (AE) is consistent with IMF World Economic Outlook (WEO) 2017.

2/ Emerging markets (EM) is based on Morgan Stanley Capital International (MSCI) 2017 categorization, with the exception of China, Czech Republic, Greece, and Korea. China is singled out as a separate category, while the rest three countries are categorized into Advanced Economies as in IMF WEO.

3/ The country group of Sub-Saharan Africa (SSA) economies is based on IMF Regional Economic Outlook (REO) 2017 categorization, with the exception of South Sudan due to data constraint.

Sources: WEO, REO, MSCI, and IMF staff compilation. 


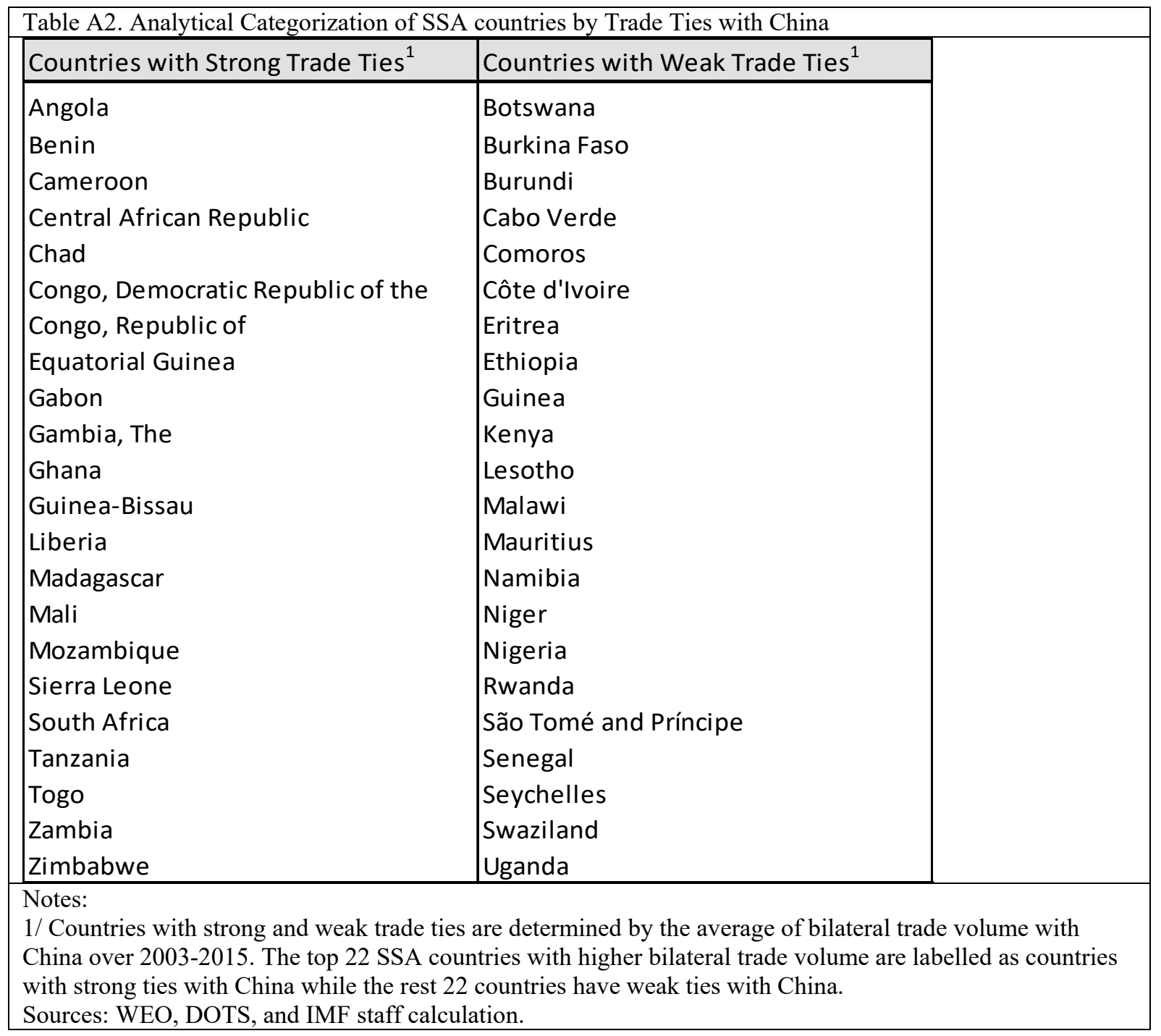




\begin{tabular}{|c|c|c|}
\hline Oil Exporters ${ }^{1}$ & Other Resource-Intensive Exporters ${ }^{1}$ & Non-Resource-Intensive Countries ${ }^{1}$ \\
\hline $\begin{array}{l}\text { Angola } \\
\text { Cameroon } \\
\text { Chad } \\
\text { Congo, Republic of } \\
\text { Equatorial Guinea } \\
\text { Gabon } \\
\text { Nigeria }\end{array}$ & $\begin{array}{l}\text { Botswana } \\
\text { Burkina Faso } \\
\text { Central African Republic } \\
\text { Congo, Democratic Republic of the } \\
\text { Ghana } \\
\text { Guinea } \\
\text { Liberia } \\
\text { Mali } \\
\text { Namibia } \\
\text { Niger } \\
\text { Sierra Leone } \\
\text { South Africa } \\
\text { Tanzania } \\
\text { Zambia } \\
\text { Zimbabwe }\end{array}$ & $\begin{array}{l}\text { Benin } \\
\text { Burundi } \\
\text { Cabo Verde } \\
\text { Comoros } \\
\text { Côte d'Ivoire } \\
\text { Eritrea } \\
\text { Ethiopia } \\
\text { Gambia, The } \\
\text { Guinea-Bissau } \\
\text { Kenya } \\
\text { Lesotho } \\
\text { Madagascar } \\
\text { Malawi } \\
\text { Mauritius } \\
\text { Mozambique } \\
\text { Rwanda } \\
\text { São Tomé and Príncipe } \\
\text { Senegal } \\
\text { Seychelles } \\
\text { Swaziland } \\
\text { Togo } \\
\text { Uganda }\end{array}$ \\
\hline
\end{tabular}

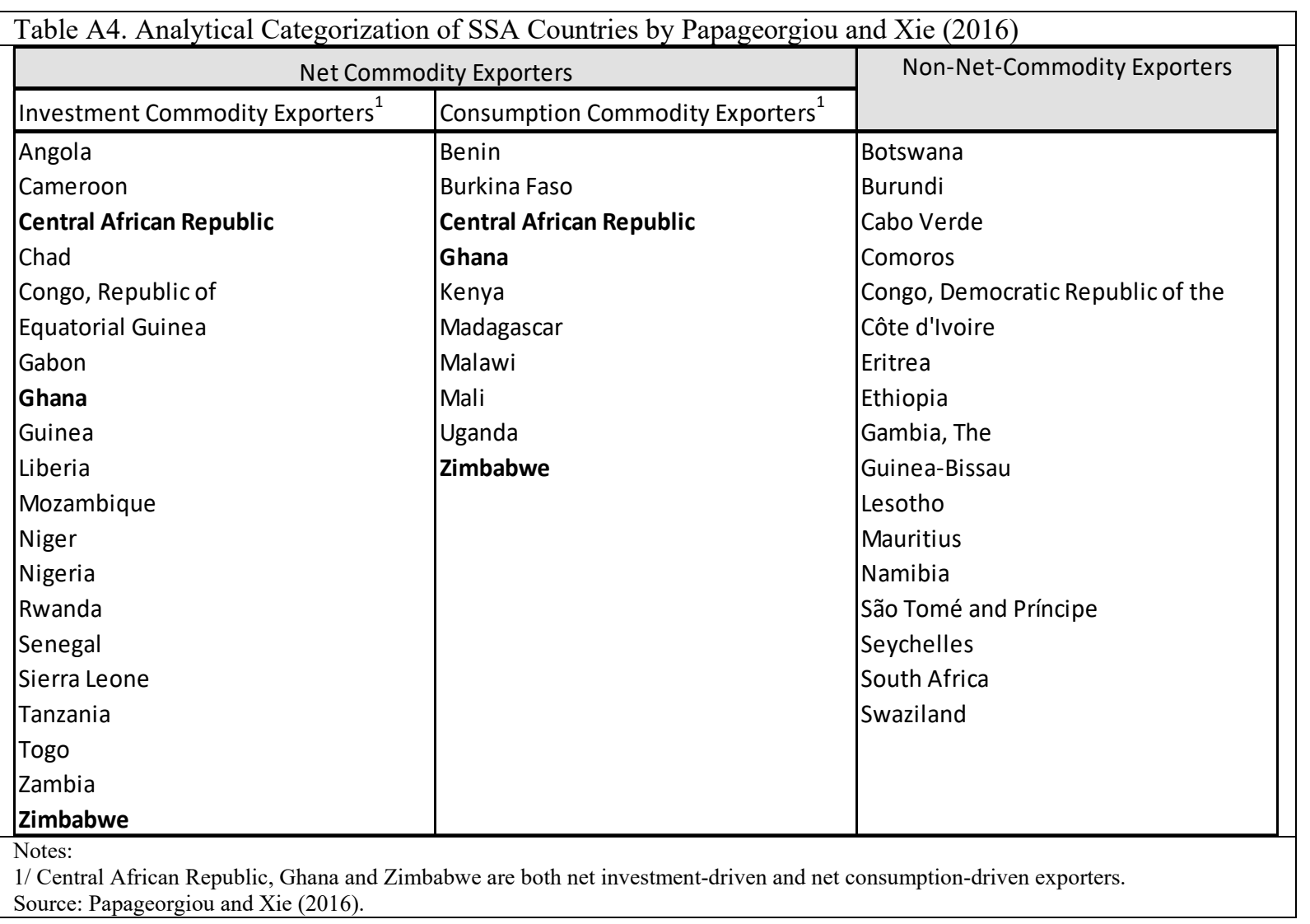

\section{CInternational Monetary Fund. Not for Redistribution}




\begin{tabular}{|c|c|c|c|c|c|}
\hline VARIABLES & Sources & mean & sd & $\min$ & $\max$ \\
\hline \multicolumn{6}{|l|}{ State Variable } \\
\hline $\begin{array}{l}\text { natural log of real GDP per capita of SSA (in } 2010 \text { USD), t-3 } \\
\text { Trade Partners' Growth }\end{array}$ & WDI & 2.292 & 0.362 & 1.608 & 3.296 \\
\hline exports-weighted growth of GDP per capita of AE, 3-year average & WEO, DOTS & 1.220 & 1.285 & -1.399 & 5.414 \\
\hline exports-weighted growth of GDP per capita of EM, 3-year average & WEO, DOTS & 2.615 & 2.197 & -11.23 & 8.763 \\
\hline exports-weighted growth of GDP per capita of peer SSAs, 3-year average & WEO, DOTS & 1.647 & 1.718 & -3.375 & 13.68 \\
\hline exports-weighted growth of GDP per capita of the ROE, 3-year average & WEO, DOTS & 1.867 & 2.194 & -4.700 & 22.17 \\
\hline growth of GDP per capita of China, 3-year average & WEO, DOTS & 7.644 & 3.176 & 0.000 & 10.74 \\
\hline \multicolumn{6}{|l|}{ Control Variables } \\
\hline fixed capital formation excluding inventory in percent of GDP, 3-year average & WEO & 18.59 & 11.93 & 0.00 & 76.02 \\
\hline government consumption in percent of GDP, 3-year average & WEO & 13.39 & 9.87 & 0.00 & 49.18 \\
\hline headline inflation (in percent), 3-year average & WEO & 17.11 & 128.90 & -26.74 & 2347.00 \\
\hline change rate of terms of trade for goods and services (in percent), 3 -year average & WEO & 1.45 & 8.53 & -41.39 & 29.91 \\
\hline the ratio of broad money (M2) in percent of GDP, 3-year average & WEO & 26.83 & 24.63 & 0.00 & 148.80 \\
\hline openness, 3 -year average & WEO & 65.38 & 44.58 & 0.00 & 250.60 \\
\hline growth of China's real consumption per capita, 3-year average & WEO & 7.31 & 2.99 & 0.00 & 9.65 \\
\hline growth of China's real investment per capital, 3-year average & WEO & 9.16 & 4.39 & 0.00 & 14.78 \\
\hline natural log of life expectancy & WDI & 3.73 & 0.68 & 0.00 & 4.31 \\
\hline Number of countries & WEO & 42 & 42 & 42 & 42 \\
\hline
\end{tabular}

\begin{tabular}{|c|c|c|c|c|c|}
\hline VARIABLES & Sources & mean & sd & $\min$ & $\max$ \\
\hline \multicolumn{6}{|l|}{ State Variable } \\
\hline natural log of real GDP per capita of SSA (in 2010 USD), t-3 & WDI & 2.322 & 0.369 & 1.756 & 3.296 \\
\hline \multicolumn{6}{|l|}{ Trade Partners' Growth } \\
\hline exports-weighted growth of GDP per capita of Advanced Economies, 3-year average & WEO, DOTS & 0.891 & 1.096 & -1.399 & 5.414 \\
\hline exports-weighted growth of GDP per capita of Emerging Markets, 3-year average & WEO, DOTS & 3.056 & 2.212 & -11.23 & 7.160 \\
\hline exports-weighted growth of GDP per capita of peer SSAS, 3-year average & WEO, DOTS & 2.177 & 1.409 & -1.993 & 9.142 \\
\hline exports-weighted growth of GDP per capita of the Rest of World, 3-year average & WEO, DOTS & 2.614 & 2.301 & -4.700 & 22.17 \\
\hline growth of GDP per capita of China, 3-year average & WEO, DOTS & 9.042 & 1.439 & 6.795 & 10.74 \\
\hline \multicolumn{6}{|l|}{ Control Variables } \\
\hline fixed capital formation excluding inventory in percent of GDP, 3-year average & WEO & 21.66 & 9.672 & 6.102 & 60.91 \\
\hline government consumption in percent of GDP, 3-year average & WEO & 15.29 & 8.202 & 2.676 & 49.18 \\
\hline headline inflation (in percent), 3-year average & WEO & 8.288 & 13.13 & -26.74 & 131.8 \\
\hline change rate of terms of trade for goods and services (in percent), 3-year average & WEO & 1.869 & 8.697 & -22.86 & 29.91 \\
\hline the ratio of broad money (M2) in percent of GDP, 3-year average & WEO & 32.57 & 24.56 & 3.223 & 148.8 \\
\hline openness, 3-year average & WEO & 77.37 & 38.97 & 23.24 & 250.6 \\
\hline growth of China's real consumption per capita, 3-year average & WEO & 8.228 & 1.273 & 6.416 & 9.492 \\
\hline growth of China's real investment per capital, 3-year average & WEO & 11.48 & 2.834 & 7.070 & 14.78 \\
\hline natural log of life expectancy & WDI & 4.034 & 0.122 & 3.706 & 4.309 \\
\hline Number of countries & WEO & 42 & 42 & 42 & 42 \\
\hline
\end{tabular}

\begin{tabular}{|c|c|c|c|c|c|}
\hline VARIABLES & Sources & mean & sd & $\min$ & $\max$ \\
\hline \multicolumn{6}{|l|}{ Key Variable of Interest } \\
\hline growth in goods exports to China (in 2010 USD) & DOTS & 30.38 & 60.68 & -53.42 & 245.0 \\
\hline \multicolumn{6}{|l|}{ Trade Partners' Growth } \\
\hline real GDP growth of China & WEO & 9.777 & 2.031 & 6.900 & 14.20 \\
\hline exports-weighted growth of GDP of AE & WEO, DOTS & 1.567 & 1.889 & -4.455 & 13.56 \\
\hline exports-weighted growth of GDP of EM & WEO, DOTS & 5.490 & 2.055 & -4.521 & 11.28 \\
\hline exports-weighted growth of GDP of peer SSAs & WEO, DOTS & 4.615 & 2.188 & -2.726 & 21.36 \\
\hline exports-weighted growth of GDP of ROW & WEO, DOTS & 3.931 & 3.074 & -8.273 & 26.62 \\
\hline \multicolumn{6}{|l|}{ Other Variables } \\
\hline headline inflation (in percent) & WEO & 7.572 & 11.63 & -72.73 & 157.0 \\
\hline change of NEER (in percent) & INS/IFS & -2.757 & 8.651 & -50.10 & 37.31 \\
\hline change of TOT (in percent) & WEO & 2.349 & 14.91 & -50.85 & 62.07 \\
\hline growth of population (in percent) & WDI & 2.563 & 0.915 & -2.594 & 4.888 \\
\hline growth of China's consumption (in percent) & WEO & 9.000 & 1.822 & 6 & 12.20 \\
\hline growth of China's investment (in percent) & WEO & 12.05 & 4.306 & 6.100 & 19.10 \\
\hline FDI from CARI database (in millions of USD) & CARI & 13.44 & 22.44 & 0 & 102.5 \\
\hline natural log of real GDP per capita of SSA (in 2010 USD) & WDI & 7.002 & 1.111 & 5.267 & 9.920 \\
\hline Number of countries & WEO & 42 & 42 & 42 & 42 \\
\hline
\end{tabular}

\section{CInternational Monetary Fund. Not for Redistribution}

